\title{
WILD PASTURES
}

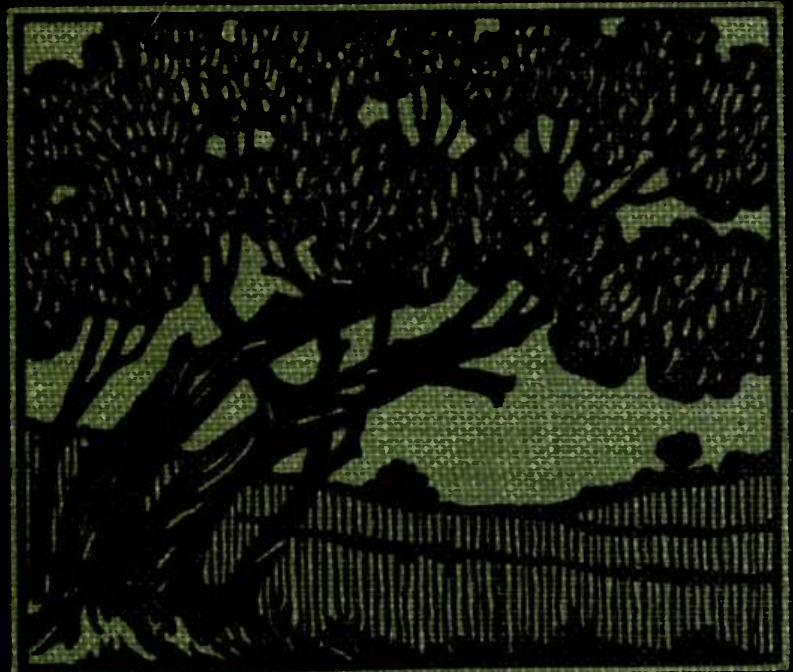

WINTHROP PACKARD 


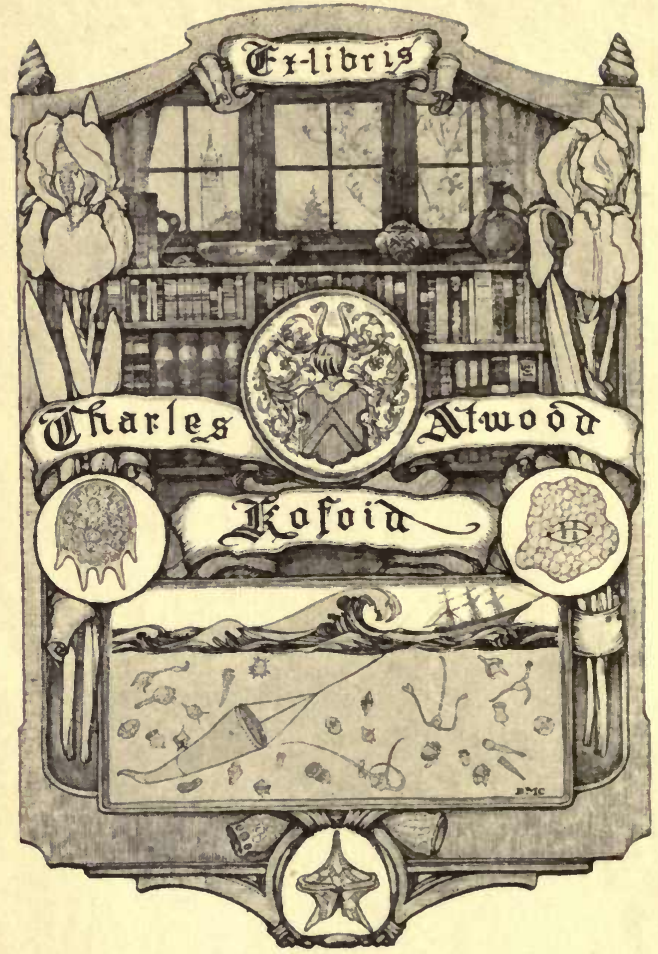




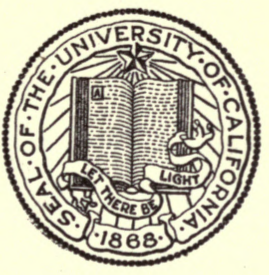

THE LIBRARY

OF

\section{THE UNIVERSITY OF CALIFORNIA}

PRESENTED BY

PROF. CHARLES A. KOFOID AND

MRS. PRUDENCE W. KOFOID 



\section{WILD PASTURES}






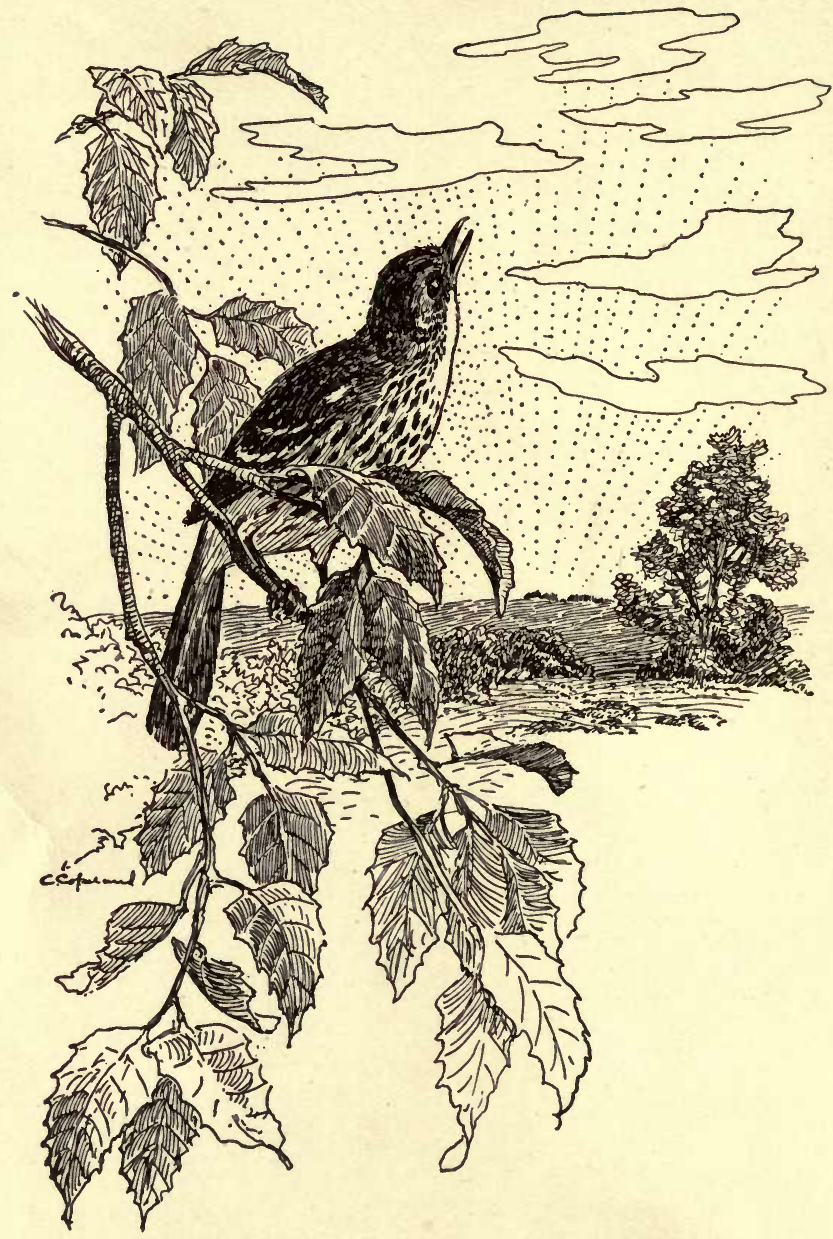

He was still sitting on his perch greeting the gold of the morning sun with melodious uproar 


\title{
WILD PASTURES
}

BY

WINTHROP PACKARD

\author{
ILLUSTRATED BY \\ CHARLES COPELAND
}

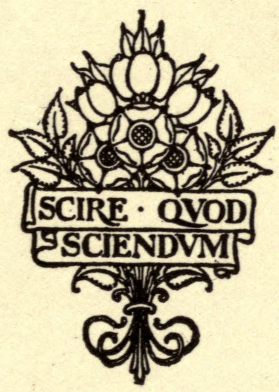

BOSTON

SMALL, MAYNARD AND COMPANY

PUBLISHERS 


\section{Copyright, 1909 JBy Imall, Maynaro \& Company \\ (INCORPORATED) \\ Entered at Stationers' Hall}

THE UNIVERSITY PRESS, CAMBRIDGE, U.S.A. 


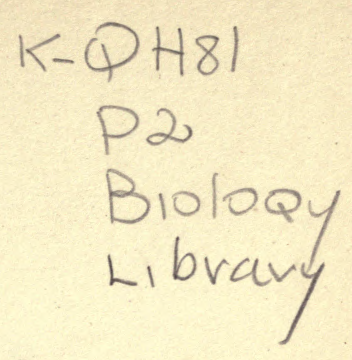

To

MY WIFE AND THE WEE BOY

WHO HAVE MADE AND SHARED

THE PASTURE SUNSHINE 


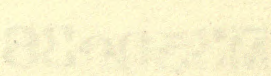




\section{CONTENTS}

PAge

WAYLAYing THE DAWN • • • • • • I

Stalking The Wild Grape • • • 25

The Frog Rendezvous . • • • • 47

A Butterfly Chase . . . . . . 69

Down Stream • • • . • • • 89

BROOK MAGIC • • • • • • . 109

IN THE PONKAPOAG BogS $\cdot . \cdot \ldots$ I3 I

Some Butterfly Friends : . . . . I5I

The Resting Time of the Birds . 173

The Pond At Low Tide • • • . 193

How the RaIN CAmE •. • . 2 I 5 


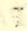




\section{ILLUSTRATIONS}

He was still sitting on his perch greeting the gold of

the morning sun with melodious uproar . Frontispiece OPPOSITE PAGE

The fox may slink for an hour unscared, waiiting with watchful eye on the neighboring chicken coop . 6

The mother bird, dancing and mincing along . . 38

Out from among the birches she sails gracefully, a veritable queen of the fairies . . . . . 64

There was the swish of wings, the snip-snap of a bird's beak, and it was all over . . . . 86

The way of the "kiver" is this. There is a single, snappy, business-like bob, then another, then three in quick succession . . . . . . 96

That such things are not seen oftener is simply because people are dull and go to bed instead of sitting out under the witch-hazel at midnight of a full moon. . . . . . . . . . . . II4

Of a clear midsummer evening you may hear the muskrat grubbing roots there ... and hear his snort and splash when he dives at sudden sight of you 


\section{ILLUSTRATIONS}

OPPOSITE PAGE

Every boy who knows the country in summer knows him by his rich, red coloration, his strong, blackbordered wings with their black veins . . . 160

The English sparrow has the true instincts of the browbeating coward . . . . . . . 180

The skunk does n't know where he is going and he is n't even on his way . . . . . . . . 198

My lone quail sat on a rock in the pasture, tipped his head back a little, swelled his white throat, and whistled . . . . . . . . . 222 


\section{WAYLAYING THE DAWN}




\section{WAYLAYING THE DAWN}

THE most beautiful place which can be found on earth of a June morning is a New England pasture, and fortunate are we New Englanders who love the open in the fact that, whatever town or city may be our home, the old-time pastures lie still at our very doors.

The way to the one that I know best lies through the yard of an old, old house, a yard that stands hospitably always open. It swings along by the ancient barn and turns a right angle by a worn-out field. Then you enter an old lane leading to what has been for more than a century a cow pasture. Here the close-cropped turf is like a lawn between the gray and mossy old stone fences that 


\section{WILD PASTURES}

the farmer of a century and more gone grubbed from the rocky fields and made into metes and bounds. There they stand to-day, just as he set them, grim mementos of toil which the softening hand of time has made beautiful. Where cattle still travel such lanes day by day these walls are undecorated, but many of the lanes are untraveled and have been so these fifty years. Such are garlanded with woodbine, sentineled by red cedars, and fragrant with the breath of wild rose, azalea, and clethra.

Side by side with this lawn-like lane is another which was once traversed by the cattle of the next farm, but which has not been used for a lifetime. In this the wild things of the wood are untrammeled, save by one another, and they hold it in riotous possession. Just as the first lane is tame and sleek this 


\section{WAYLAYING THE DAWN}

other is wild and unkempt. The raspberry and blackberry tangle catches you by the leg if you enter, as if to hold you until birch and alder, cedar and sassafras, look you over and decide whether or not you are of their lodge. If you give them the right grip you may pass. If not, you will be well switched and scratched before you are allowed to go on.

Here the wild grape climbs unpruned from wall to cedar, from cedar to birch and from birch to oak, whence it sends its witching fragrance far on the morning air. You may stalk a wild grape in bloom a mile by the scent and be well rewarded by finding the very place where the air tingles with it.

This lane is wild, and the wild things of the woods that come on fleet wing and nimble foot frequent it. You may 


\section{WILD PASTURES}

never see a partridge in the sleek lane, and if by chance the red fox crosses it he does so gingerly and as if it were hot under foot. In the other, however, the fox may slink for an hour unscared, waiting with watchful eye on the neighboring chicken coop, the red squirrel builds his nest in the cedar, and the partridge leads her young brood among the blackberry bushes of an early morning.

The azalea sends out its white fragrance from the one lane, and never a buttercup, even, nods to the wind in the other; yet you love the smooth shorn one best. It talks to you of the homely life of the farm, the lazy cattle drowsing contentedly to the barn at milking time while the farmer's boy sings as he puts up the bars behind them. You love it best because, however much you may 


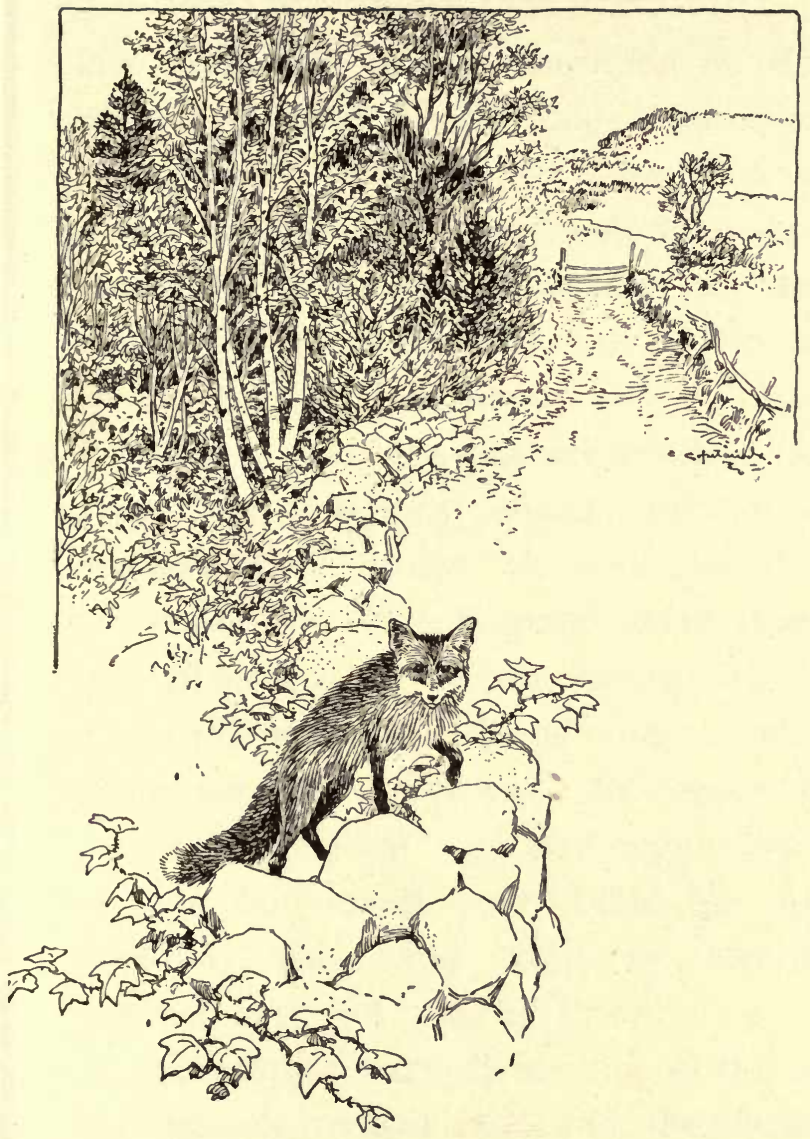

The fox may slink for an hour unscared, waiting with watchful eye on the neighboring chicken coop 



\section{WAYLAYING THE DAWN}

love the wild things, the lure of the home-leading and well-trodden paths is strong upon you. It is more than a sturdy, rough-built stone wall that separates the two lanes; there is all the long road from the wilderness down to civilization between them.

For the story the pasture teaches us, more than anything else is the story of how the fathers wrested the dominion of the New England earth from the wilderness and of the way in which the wilderness still hems their world about and not only waits the opportunity to spring upon us and regain possession, but invests our fields like an invading army and takes by stealth what it may not win by force.

The pasture bars divide the world of the smooth-trodden lane and the closeshorn fields from the picket line of the 


\section{WILD PASTURES}

wilderness. Let us pause a moment upon the line of demarcation. Behind us are the entrenchments of civilization, the farmhouse and barn and other buildings, - its fort. The town road is the military way leading from fortified camp to fortified camp, the mowing field its glacis, and the stone walls its outer entrenchments. These the cohorts of the wilderness continually dare, and are kept from carrying only by the vigilance of the farmer and his men.

Let but this vigilance relax for a year, a spring month even, and bramble and bayberry, sweet fern and wild rose, daring scouts that they are, will have a foothold that they will yield only with death. Close upon these will follow the birches, the light infantry which rushes to the advance line as soon as the scouts have found the foothold. 


\section{WAYLAYING THE DAWN}

These intrench and hold the field desperately until pine and hickory, maple and oak, sturdy men of the main line of battle, arrive, and almost before you know it the farm is reclaimed. The wilderness has regained its lost ground and the cosmos of the wild has wiped out that curious chaos which we call civilization.

In this debatable land of the pasture, this Tom Tiddler's ground where the fight between man and the encroaching wilderness goes yearly in favor of the wilderness, dwell the pasture people. The woodchuck, the rabbit, and even the fox have their burrows here, the woodchuck and the rabbit finding the farmer's clover field and garden patch a convenient foraging ground, the fox finding the chicken coop and the rabbit equally convenient. 


\section{WILD PASTURES}

The pasture is the happy huntingground of the hawks and owls; though they dwell by preference in the deep wood, the nearer approaching to the forest primeval the better, but the crow often nests in a pine among a group of several in the pasture. The pasture is peculiarly the home of scores of varieties of what one might term the half wild birds, the thrushes from honest robin down to the catbird, warblers, finches, and a host of others who are as shy of the deep woods as they are of the highway; and here, in those magic hours that come between the first faint flush of dawn and sunrise, you may hear the full chorus of their matins swell in triumphant jubilation.

Here in Eastern Massachusetts the dawn comes early, very early, in June. It will be a little before three that if 


\section{WAYLAYING THE DAWN}

you watch the east you will see it flush a bit like the coming of color on the face of a dark-tressed maiden who has had sudden news of the coming of her lover. This flush of color fades again soon, and it is evident that it is all a mistake, for the darkness grows thicker than ever, and night, like that of the Apocalypse, is upon the face of the world. The dawn is long coming when you wait for it. Joshua evidently has arisen and is holding the sun in Syria as of old, that he may have time further to confound his enemies.

No one believes that there will be dawn at all. You cannot prove it by the wood thrush. He sings best, indeed he sings only, in the shadow, and often even in the darkest night he will send out a bell-like note or two that has a soothing, sleepy tintinnabulation as of 


\section{WILD PASTURES}

cow-bells shaken afar off by drowsy cattle. No, the wood thrush is not a reliable witness, but if you are wise in the ways of field and pasture before dawn, you may take evidence from the chipping sparrow. He is the earliest as he is one of the smallest of the morn-waking birds. In his case the least shall be first. I do not know if he really sees the dawn or if he smells it. There is a change in the air before there is in the sky, and perhaps he notes it. Perhaps, too, being smaller, he needs less sleep than the other birds, and his gentle inquiring note is a plaint that the night is long rather than a prophecy that it is ending. But it is he that first predicts with certainty the coming day, and it will be many minutes after his first call before the growing luminosity, a sort of pale halo that looms slowly 


\section{WAYLAYING THE DAWN}

about all things, tells you that the sun is indeed coming. Even then you are likely to hear no other bird note for what seems a long time.

Then from a treetop in the open comes a sort of surprised ejaculation, as if some one said, "Why, bless me! It is morning already," and then a burst of song from the full throat of a robin. It is as if he were the chorister of a choir invisible, for he pipes but a single strain before from treetop to treetop, near and heaven only knows how far, bursts forth the mingled melody of a great chorus of robins ringing clarion notes of jubilee.

They have the overture to themselves all along in the open, for there the song sparrow does not sing till some ten minutes later. Of these again you shall hear a single bird, followed by a 


\section{WILD PASTURES}

chorus in the next breath, and close upon the heels of the sparrow voice come the notes of innumerable warblers of many kinds whose songs you shall not distinguish one from another and name unless you are an expert. Behind these again come the chewinks and thrashers, not so early risers by any means, and very late the catbird. The catbird is clever but, like many clever people, he is lazy.

Over to the other side of the pasture, a mile from the lane as the crow flies, is a swamp which is part of the pasture, indeed, but a part of the wilderness beyond, also. It was on the edge of this that I had chosen to meet the dawn, picking my way to it through the darkness in part by scent, for the swamp has a musky fragrance of its own, which it sends far on the night air. Coming 


\section{WAYLAYING THE DAWN}

down the slope to it you pass through a tangle of scrub oak that leads you to a lower region of alders snarled with greenbrier - "horse brier" we call it familiarly.

Here the ground begins to be soft, with occasional clumps of sphagnum moss, which is like a gray-brown carpet of velvet, not yet made up, but tacked together with yellow bastings of the goldthread. Among the scrub oaks a stately pine here and there shoulders up, sending you a reassuring sniff of pitchy aroma. The scrib oaks know their allotted ground and cease wandering when their toes touch swamp water, but the pines are more venturesome, and often lift with their roots little mounds of firm brown carpeted ground in the midst of the quaky sphagnum. Slender cedars crowd in from the swamp 


\section{WILD PASTURES}

toward these pines, plumed like vassal knights that rally to the support of their overlord.

On one of these pine islands on the edge of the swamp an oven bird had built her nest, and on this particular night in June she was in much distress because she could not get into it. The oven bird builds a nest on the ground among low bushes and vines, choosing often a spot where pine needles are scattered among the dead leaves. She roofs this nest with care - and dried grass - and builds a tunnel-like entrance to it so that you may see neither the eggs nor the bird sitting on them. You may step on an oven bird's nest before you will see it, even when looking for it, and you may know for a certainty that it is within a definite small patch of ground, and yet hunt long before I6 


\section{WAYLAYING THE DAWN}

you find it. The mother bird had been frightened from her nest by the crush of my foot at its side in the darkness, and she did not dare come back, for I had unwittingly sat down beneath the pine almost across the entrance. Frightened for her nest as well as herself, she fluttered about like a bird ghost, now dozing in the thicket for a time, then waking to strangeness and fear, and making her plaint again.

The wood thrush, brooding her eggs in the thicket near by, heard it and was wakeful, and her mate, never far off, now and again lifted his head from beneath his wing and drowsily tintinnabulated a reassuring note or two, but I did not stir. I was not sure that I was the cause of the oven bird's trouble, and if so to move about in the darkness might well bring her worse disaster. 


\section{WILD PASTURES}

The false dawn reddened and vanished, the gray of the real dawn was streaked and then flushed with rosy light shot through with gold, and a thousand voices of jubilee rang from treetop to treetop the whole pasture through and far out into the wood beyond, and still I waited, stretched motionless. A man might have thought me dead, the victim of some midnight tragedy, but the denizens of the pasture are wiser in their own province than that.

In the gray of that first dusk, that was hardly streaked with the reassuring red of dawn, a crow slipped silent and bat-like from the top of a neighboring pine. In that twilight of early dawn you could not see him continually as he flapped along. The motions of his wings gave him strange appearances I8 


\section{WAYLAYING THE DAWN}

and disappearances as if he dodged back and forth, flitting up under cover of pillars of mist, yet there was no mist there, only the uncertainties of early light which seems to come in squads rather than in company front. This crow turned suddenly in his flight as he neared my pine island in the swamp and lighted in noiseless excitement on a dead limb. A moment he craned his neck, peering sharply at my motionless figure. The crow is at times a scavenger, and if there were dead men about he wanted to know it. For that matter if there was anything else about he wanted to know it, for the crow is likewise a gossip. A moment then he gazed at the motionless figure, then he vaulted from the limb and the vigor of his call resounded far and near as he flapped away eastward into the crimson. 


\section{WILD PASTURES}

"Hi! Hi! Hi!" he shouted. "Fellow citizens, there's a man in the woods here. $\mathrm{He}$ is motionless, but he is only making believe dead. Look out for him!"

Far and near the cry rang and was taken up by others of his tribe who passed the word along. "There's a man in the woods!" they shouted, "look out for him." The birds singing near by ceased their songs for a moment that they might have a look at the man, for they understand the crow's note of warning as well as if they too spoke his language.

The thrushes were singing now, and after a while the catbird, lazy reprobate, awoke. He too, like the crow, is a gossip, and more than that he is a tease. He shook his head a little to straighten the ruffled feathers of the neck, 


\section{WAYLAYING THE DAWN}

disturbed by their position for the night. He stretched one leg and the wing on that side simultaneously, then the other leg and the other wing, a bird yawn as expressive as the human one. Then he cocked his head on one side with a gesture of pleased surprise and excitement and said, "Mi-a-aw!" $\mathrm{He}$ too had seen the invader of the swamp.

The catbird is a good singer, that is, a good mimic. His taste is good, too, for he imitates only the best. Here in the North he imitates the brown thrush, no doubt, all things considered, our best vocalist. So well does he imitate him that you shall not say of a surety that this is the catbird singing and yonder is the thrush. In the South he imitates the mocking-bird with equal fidelity. You would say on casual acquaintance that he was our ablest singer and most ex- 


\section{WILD PASTURES}

emplary bird as he masquerades in the voices of others, but let him once be frightened, or angered, or over-excited about anything and the reprobate part of him reasserts itself and he says " $\mathrm{Mi}$ a-aw!" Hence his name, the catbird.

The catbird, however, has the courage of his convictions, and one of these convictions is that he has the right to the satisfaction of an ungovernable and enormous curiosity. Bait your bird trap in the woods with something which strikes a bird as a curiosity that courts immediate investigation and you will catch a catbird. Other birds might start for it but the catbird would distance them. So, after saying “Mi-a-aw!" a few times and drawing no response to his challenge, he flew up to a twig within a foot of my head, sat there a moment, motionless except his beady 


\section{WAYLAYING THE DAWN}

black eyes which traversed my form from foot to head, finally resting on my eyes. Inadvertently I winked; that was the only motion I made, but it was enough. With a flirt of his tail and a flip of his wings the catbird was through the thicket and out on the other side like a gray flash, scolding away at the top of his voice and seeming to shout as the crow had, "There's a man in the wood! There's a man in the wood! Look out for him!"

The crimson and gold of the dawn had softened and diffused into diaphanous mother-of-pearl mists of early day. The June morning miracle was complete and it was high time I allowed the oven bird to come back and be assured that her nest and eggs were safe. 
$\checkmark$ . 
STALKING THE WILD GRAPE 



\section{STALKING THE WILD GRAPE}

$\mathbf{I}_{\mathrm{T}}$ was to be a moonlight night, yet the moon was on the wane and would not rise until eleven. It seemed as if the pasture birds missed the moon, or expected it, for beginning with the June dusk at eight o'clock one after another made brief queries from red cedar shelter or greenbrier thicket. One or two indeed insisted on pouring forth snatches of morning song, sending them questing through the darkness for several minutes, then ceasing as if ashamed of having been misled.

The cuckoo, of course, you may hear often on any warm night, springing his watchman's rattle chuckle from the denser part of the thicket. But for the brown 


\section{WILD PASTURES}

thrush to be announcing morning every half-hour through the darkness was an absurdity to be accounted for only on the theory that here was a gay young blood who was practising for a moonlight serenade. And when the moon did come, touching the tops of the pines first with a fine edging of gold, dropping a luminous benediction to the birches and diffusing it lower and lower till the whole pasture was gold and dusk, the ecstasy of the thrush knew no limit. He poured forth a perfect uproar of liquid melody, punctuated with such hurroos and whoops of delight that he made me wonder if his lady love would like such college-song methods of serenading.

I sat up from my couch on the green moss under the huckleberry bush to listen. The people of the pasture seemed 28 


\section{STALKING THE WILD GRAPE}

to have trooped up to the call of the music. The red cedars, the birches, the huckleberry bushes in the daytime have individuality indeed, but in the nighttime they have personality. They loom up in spots where by day you did not notice them at all. Some red cedars stand erect and stiff as military men might on sentinel duty, others gowned in black like monks of old group together and seem to consult, while all about them mingling in gracious beauty are the birches and the berry bushes, the birches slender, dairity aristocrats gowned in the thinnest of whispering silk, the berry bushes sturdy and comfortable in homespun. You are half afraid of the cedars, they are so black and seem to watch you so intently, more than half in love with the birches, so graceful and enticing, as they lean 


\section{WILD PASTURES}

toward you in their diaphanous drapery, but it is the berry bushes shouldering up to greet you in hearty bourgeois welcome that make you feel at home.

I listened to the thrush, but soon I found that I had only one ear to do it with, for on the other side of me a bird was rapidly approaching with greater and equally persistent clamor. It was a whip-poor-will, seemingly roused to rivalry by the challenge of the thrush. So far as I know the thrush paid no attention to him but simply kept up his song in the birch near by, but the whippoor-will came up little by little till he seemed almost over my head, and I could hear plainly the hoarse intake of breath between each call. Very brief gasps these intakes were, for the whippoor-wills fairly tumbled over one another without cessation. 


\section{STALKING THE WILD GRAPE}

Now the bird went away for a distance, again he came back, but always he kept up his call, while the thrush never wavered from his perch in the birch. A dozen times I waked in the night to find them still at it, and when the gray of dawn finally silenced the whip-poor-will, the thrush let out like a tenor that has just got his second wind. He sang up the dawn and the grand matutinal bird chorus, and the last I heard of him he was still sitting on his perch greeting the gold of the morning sun with melodious uproar.

A blind man who knows the pasture should know what part of it he is in and the pasture people that are about him of a June morning simply by the use of his other senses. The birds he would know by sound, the shrubs and trees by smell. Each has its distinctive 


\section{WILD PASTURES}

set of odors differing with differing circumstances, but never varying under the same conditions. The barberry fruit when fully ripe, especially if the frost has mellowed it, has a faint, pleasant, vinous smell which, with the crimson beauty of the clustered berries, might well tempt our grandmothers to make barberry sauce, however much the men folk might declare that it was but shoe-pegs and molasses.

The blossoms are equally beautiful in their pendant yellow racemes which seem to flood the bush with golden light, but the odor of the blossoms, though the first sniff is sweet, has an after touch which is not pleasant. Crush the leaves as you pass and you shall get a smell as of cheap vinegar with something of the back kick of a table d'hôte claret. Crush the leaves of 


\section{STALKING THE WILD GRAPE}

the swamp azalea and get a strawberrymusk flavor that is faint but delightful.

Sniff as you shoulder your way through the high blueberry bushes and you may note that the crushed leaves have a certain vinous odor like one of the flavors of a good salad. The blossoms of the high-bush blackberry, whose thorns tear your hands, have a faint and endearing smell as of June roses that are so far away that you get just a whiff of them in a dream. The azalea that a month later will make the moist air swoon with sticky sweetness now gives out from its leaves something that reminds you of wild strawberries that you tasted years ago. It is as delicate and as reminiscent as that.

Under your foot the sweet-fern breathes a resin that is "like pious incense from a censer old," the bayberry 


\section{WILD PASTURES}

sniffs of the wax of altar candles lighted at high mass in fairy land, and over by the brook the sweet-gale gives a finer fragrance even than these. There are but three members of this family, - the Myrica or Sweet-Gale family, - yet it is one that the pasture could least afford to miss. The fragrance of their spirits descends like a benediction on all about them, and I have a fancy that it is steadily influencing the lives of the other pasture folk.

I know that the low-bush black huckleberry, the kind of the sweet, glossy black fruit that crisps under your teeth because of the seeds in it, grows right amongst sweet-fern whenever it can. Now if you crush the leaves of the lowbush black huckleberry you shall get from them a faint ghost of resinous aroma which is very like that of the 


\section{STALKING THE WILD GRAPE}

sweet-fern. Thus do sweet lives pass their fragrance on to those about them.

Many of these familiar odors had come to me during the night as I half slept and half listened to the vocal duel between the thrush and the whip-poorwill, but as I sprang to my feet at sunrise from my dent in the pasture moss I got a whiff of another which seemed more subtly elusive, more faintly fine than these, perhaps because, though I seemed to recognize it, I could not name it.

Many things I could name as I have named them here, but this escaped me. It had in it some of that real fragrance, a joy without alloy, which you get in late July or August from the clethra, the white alder which lines the brook and the pond shore with its beautiful clusters of odoriferous white spikes. 


\section{WILD PASTURES}

But by no stretch of the imagination could I bring the white alder to bloom in early June. Moreover, it had only a suggestion of that in its purity of fragrance. There was more to this. There was a spicy, teasing titillation that made me think of bubbles in a tall glass, and it is a wonder that that thought did not name it for me, but it did n't.

The sun was tipping the dew-wet bush tops with opal scintillations that soak you to the skin as you shoulder through them, but that did not matter; I was dressed for it, and so on I went, taking continual shower-baths cheerfully, but always with that teasing, alluring scent in my nostrils. Now and then I lost it; often it was confused and overridden by other stronger odors. Once I forgot it. 


\section{STALKING THE WILD GRAPE}

That was when I sprang over a stone wall and landed fairly in the middle of a covey of partridges made up of a mother bird and what seemed a small whirlwind of young ones no bigger than my thumb. My plunge startled the mother so that she thundered away through the bushes, a thing that a mother partridge, surprised with her young, will rarely do. At the same moment the young scurried into the air. It was like a gust among a dozen brown leaves, whirling them breast high for a moment and then letting them settle to earth again. You go to pick them up and they surely are brown leaves! It is as if some woodland Merlin had waved his wand. They were young partridges, they are brown leaves. It is as quick as that.

Yet this was my lucky morning, for 


\section{WILD PASTURES}

one of these little birds failed to dematerialize, and I noted him wriggling down under a clump of woodland grass and picked him up. He made pretense of keeping still for a moment, then wriggled in fright in my hand, a pathetically silent, frightened, brighteyed little chick, mostly down. How his few feathers helped him to make as much of a flight as he had is beyond my conception. He must have mentalscienced himself up into the air and down again.

Holding him gently, I pursed my lips and drew the air sharply in between lips and teeth. The result was a peculiar squeaking chirp which I have often used on similar occasions with many different birds and almost always with success. Then there came a sudden materialization. Out of the atmosphere, 38 


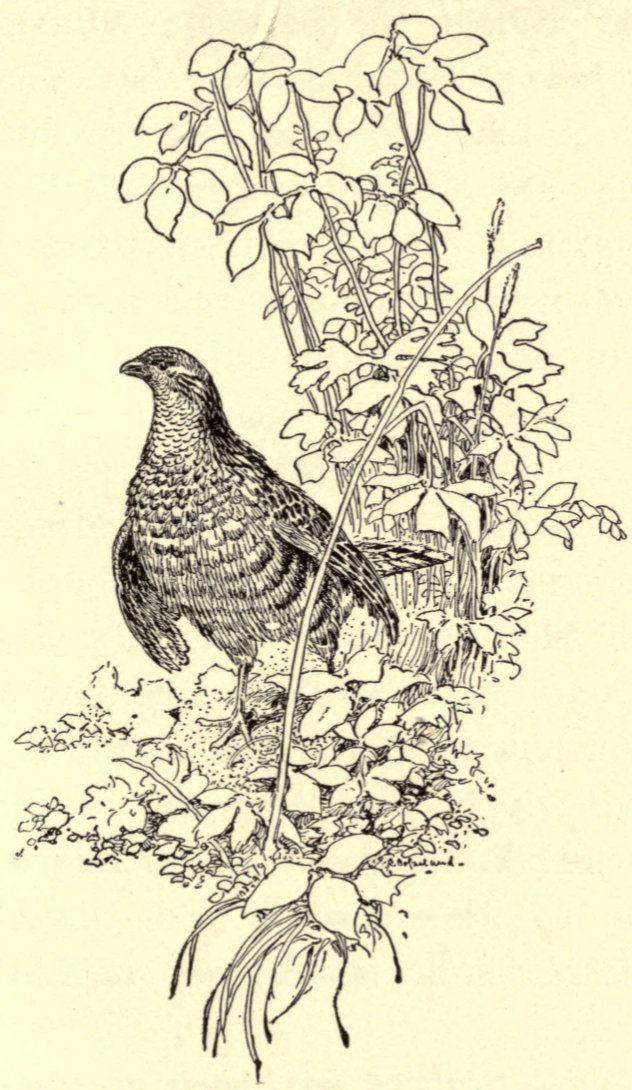

The mother bird, dancing and mincing along 


\section{STALKING THE WILD GRAPE}

apparently, appeared the mother bird, dancing and mincing along toward me till she was very near, her head up, her eyes blazing with excitement, her wings half spread and her feathers fluttering.

It was a sort of pyrrhic dance by a creature as different from the usual partridge as may be conceived. It lasted but a moment; at a sudden, indescribable note from the mother bird the fledgling gave an answering jump and slipped from my relaxed hold, fluttered and dematerialized before my eyes just as the mother bird went into nothingness in the same way. Truly, there are bogies in the wood, for that morning I saw them at their work. It was the illusion and evasion of old Merlin; no less.

Going on down the pasture, I picked up the musky scent of the swamp I was 


\section{WILD PASTURES}

approaching, instead of the thing I sought. The scent of the swamp is cool with humid humus, musky with the breath of the skunk-cabbage, woodsy with that quaint exhalation which you get from the ferns, our oldest form of plant life, still retaining and lending to you as you pass the odor of the very forest primeval. These are the base, and they carry the lighter and daintier odors as ambergris, a vile and dreadful but very strong smell, carries the dainty scents of the perfumer, and just as they in turn give you no hint of the ambergris which is their base, so the odor of the swamp gives you little hint of these three but is a delight of its own.

Beyond the little corner which I must cross in the straight line I had taken was a small hillock of open pasture, fringed on the farther side with alder 


\section{STALKING THE WILD GRAPE}

and button bush which stand ankle deep in the water of the pond. Here on the little knoll daisies sent out that faint, hay-like smell which is common to most of the compositæ. The squaw weed in the meadowy edge between the swamp and the knoll had given me the same fragrance. But standing on the top of the knoll while the soft morning wind swept the daisy fragrance by me knee high, I caught, head high, the elusive, alluring odor that I was seeking. It led me down to the pond side and called me, dared me, to come on. "Why not? I was dressed for it, and I was wet to the skin with the drench of the morning dew already.

The cove was but a hundred yards across, and I stood on the bank wishing to note carefully the direction I must take. The lazy morning wind drifted 


\section{WILD PASTURES}

across, just kissing the water here and there, leaving the surface for the most part smooth. I wet my finger and held it up, dropping it cool side down till it was level. It pointed exactly toward the opposite point at the other side of the cove and between it and the next one. There a low, sloping, broad flat rock hung with a canopy of green leaves was the dock at which I might land conveniently, and I splashed resolutely into the water, scaring almost to death with my plunge a big green frog that was sunning himself on a little foot-square cranberry bog island. $\mathrm{He}$ gave a shrill little yelp of terror and dived before I could.

Singular thing that little half squeak, half screech, of alarm. I have heard a girl make an almost identical sound when coming suddenly on a particularly 


\section{STALKING THE WILD GRAPE}

fuzzy and well-developed caterpillar. Rabbit, dog, and bird have it as well; indeed, it seems to be the one word which is common to all races and to all articulate creatures. Like the scent of brakes it began with the beginning of things and has survived all the changes of creation.

The muskrat ferry is a pleasant one. Little dancing sprites of mist, the height of your head above water, tiptoe off the surface and slip away as you swim toward them. You may see these only of a morning when you take the muskrat ferry. They are invisible from the shore or from the height of a canoe seat.

It is probable that just as some of the pasture people make sounds too shrill or too soft for our human ears to hear them, so there are other things 


\section{WILD PASTURES}

about the pasture less visible even than the little mist folk that we might see were our sight fine enough or soft enough.

Two-thirds of the way across a little puff of wind sparkled its way out from the shore to meet me. It brought with it, full and rich, the fragrance which had led me so long; and as I looked at the broad leaves overhanging my rock port, their under sides and the young shoots covered with a soft, cottony down, I laughed to think that I should not have known what it was I sought. For it was there in plain sight; indeed the rock was canopied with it.

A long time I sat on that rock on the farther side of the cove, the June sun warming me, the fragrance of the foxgrape blooms over my head alluring, 


\section{STALKING THE WILD GRAPE}

soothing, wrapping my senses in a dreamy delight.

He who would attempt to classify and define the perfume that drifts through the pasture from the bloom of the foxgrape may. I only know that it makes me dream of pipes of Pan playing in the morning of the world, while all the wonder creatures of the old Greek myths dance in rhythm and sing in soft undertones, and the riot of young life bubbles within them.

The pasture, indeed, could ill afford to lose the pious incense from the sweetfern's censer, the fragrance of the altar candles of the bayberry, and the subtle essence of the sweet-gale. These are the holy incense of the church of out-ofdoors, and it is well that we should always find them when we come to worship; yet he who would dare all to steal 


\section{WILD PASTURES}

for one elusive moment the fragrance of the deep heart of delight, let him come to the pasture on just that rare, brief period of all the year when the fox grape sends forth its perfume. 
THE FROG RENDEZVOUS 



\section{THE FROG RENDEZVOUS}

THE pasture meets the pond all along for a mile or so. It lays its lip to it and drinks only here and there. It drinks deepest of all in a cove. You will hardly know where pasture leaves off and cove begins, the two mingle so gently. The pasture creatures here slip down into the cove, and those of the pond make their way well up into the pasture. You yourself, approaching the cove from the pasture side on foot, will be splashing ankle deep in it before you know you are coming to it at all, so well do the pasture bushes, standing to their knees in the cool water, screen it from you.

Coming from the pond side you might 


\section{WILD PASTURES}

think you saw the margin in this same screen of bushes, but there are roods of cove beyond and behind them. The shrubs of the pasture love to come down and dabble their feet in the warm pond water and sun themselves in the sheltered, fragrant air.

The afternoon sun has more resilience here than elsewhere. It bounds with fervent flashes of elasticity from the glossy leaves of the bushes that have waded out farthest and made islands of themselves. The high-bush blueberries are the most daring of all, and stand in the largest clumps farthest out. These, late in May with an offshore wind, shower the whole surface of the water with their fallen corollas. More than once have I seen the cove white with them on Memorial Day, as if the bushes, standing with 


\section{THE FROG RENDEZVOUS}

bowed heads, strewed the waves with memorial flowers for the pasture people who have died at sea.

Earlier in the year the elms have made the whole surface of the cove brown with their round, wing-margined seeds, and after the memorial flowers of the blueberry bushes are gone the maples will send out millions of two-sailed seed boats, reddening the whole surface with their argosies as they go out - to sea, wing and wing. Now all these things have passed and the surface of the water is clean again to dimple with the under-water swirl of a minnow-hunting pickerel or lap lazily against your canoe with the dying undulations of the waves from outside.

After the bold blueberry bushes, less daring but still eager pasture people have waded in and formed lesser 5I 


\section{WILD PASTURES}

island clumps of their own. These were led by the sweet-gale, holding her darkgreen silken skirt daintily up, so fragrant-souled that she fears no evil, trailed by the saucy wild rose, cheerful spirea, gloomy cassandra, and chubby baby alders. If you watch these you will note that they shiver in the lazy breeze as if they feared the pass to which their temerity may have brought them. Yet there they stand, and the miniature tides swirl about their pink toes and die in the pools behind them, so closely grow the sedges and little marsh plants that fill them until the fishes from the cove nose about their stalks in vain attempt to enter.

Just outside the bush fringe, where the maples are mirrored in undulations, whirl and skip, each according to his kind, the surface insects of the cove. 


\section{THE FROG RENDEZVOUS}

Of these I hail with greatest joy, as any boy should, the "lucky bug." You know the one I mean. He is a third of an inch long, almost as broad, oval, a sort of whaleback monitor without any turret. He is hard shelled and a Baptist, judged from the pertinacity with which he sticks to deep water, but a Baptist gone sadly wrong, for he waltzes continually with his fellows. Round and round they go in a mazy whirl that would make you dizzy if at the last gasp they did not reverse.

All boys who fish know that these bugs carry stores of luck within their hard shells, and for one even to approach your line in his mad waltz is a sign of coming success, and should he actually touch the line and cling, it presages a big fish. But if you would propitiate the gods in most definite fashion 


\section{WILD PASTURES}

before you cast line you should catch several lucky bugs, the more the better, bury them on the bank with their heads to the shore, and recite over them an incantation as follows:

"Bug, bug, bug,

I've spit on the worms I dug;

Bug, bug, give me my wish,

A great big string of great big fish."

Properly managed this was never known to fail; if it does it is because you have buried one or more of your bugs bottom up.

It is not so easy to catch a lucky bug, however. $\mathrm{He}$ is a very modern type of monitor, for his engine power is of the highest, steam is always at the top notch, and he can dart away in a straight line with all the concentrated fury of a torpedo boat. Moreover, he is 


\section{THE FROG RENDEZVOUS}

convertible, and I have seen him when completely surrounded by enemies become a submarine and dive straight for the bottom and stay there. He may have an oxygen tank; anyway, he does n't come up until he gets ready, when he appears fresh and hearty and ready for another waltz.

A fellow surface sailor of his, or rather skipper, is a different type of bug. This is the water-strider, a veritable Cassius of the cove, with the lean and hungry look of an overgrown, underfed mosquito. There is no merry waltz with his fellows about this piratical-looking chap. He spreads his four long legs like a Maltese cross, and the tips of them are all that touch the water. These dent it into minute dimples, but do not penetrate, and his bugship skips energetically about on the 


\section{WILD PASTURES}

four dents, hopping at times like a veritable flea. Sometimes he jumps a half-inch high and skitters along the surface as a boy skips a stone; again he poises, lowers his body till it all but rests on the water, then raises it till he is high on four stilts, and all the time not even his toes are wet.

Entering the cove in mid-afternoon you might think the swooning heat had left it no life awake other than the water insects and the dragon-flies that race them in airship fashion above. Yet you have but to ground your canoe on a sedgy shallow, sit motionless, and wait. Nor have you to wait long. There is a breathless pause as if all things waited to see what this leviathan of the outer deep meant to do next; then a voice at your very elbow says reassuringly, “Tu-g-g-g!" That is as 


\section{THE FROG RENDEZVOUS}

near as you can come to it with type. There are no characters that will express its guttural vehemence which strikes you like a blow on the chest, or its sympathetic resonance. Take your violin, drop the $\mathrm{G}$ string to a tension so low that it will hardly vibrate musically, then twang it. That suggests the tone. But you know it well enough without description.

Immediately there comes an answering chorus of "tu-g-gs," here, there, in a score of places all along the shore line and among the island clumps of bushes, prelude of frog talk galore for a moment or two, followed by brief silence. Then, taking advantage of the oratorical pause, an old-timer sets up a tremendously hoarse and vibrant bellow. "A-hr-r-h-h-u-m-mm!" he says, "A-hr-r-h-h-u-m-mm!" with the accent 


\section{WILD PASTURES}

on the rum. You can hear him half a mile, and immediately there is a "chug-squeak-splash" from a little fellow, as if, unable to furnish the beverage at short notice, he became affrighted and without delay decided that a sequestered nook on bottom between two stones was for him. Then the cove goes to sleep again; you can almost hear the silence snore.

Little by little, if you look about you shall see them, some right within reach of your paddle. I never know whether they slip under when the canoe approaches and bob up again noiselessly after all is still, or whether they are there all the time, only so well concealed by nature that the eye does not note them at first; but I do know that you never see them until you have waited a bit. Their brown backs are just under 


\section{THE FROG RENDEZVOUS}

water, their green-brown heads just enough above the surface so that the nostrils will get air; and there they wait, motionless, for hours and hours, for time and tide to serve luncheon. Even with only the tops of their heads visible they make you laugh, for their pop eyes are popped so high above the tops of their flat heads that they make you think of automobile bug lights set well up above the motor hood.

I note a shipwrecked June beetle clinging half drowned to a spear of grass and I toss him over within six inches of a frog. There is a splash, a gulp, and the beetle with his frantically clawing, thorny-toed legs is passed on to kingdom come without a crunch. Once or twice after that this frog stirred as if he had an uneasy conscience, but he seemed to suffer no in- 


\section{WILD PASTURES}

ternal pangs, indeed he winked the circular yellow lining of his eye at me these times as if he enjoyed it. It had all the effects of smacking the lips.

The afternoon dreams down from its pinnacle of hazy heat to the soft level of eventide. Under the pines of the west side of the cove the level sun slips in and seems to caress the green trunks, and the tops above sing a little sighing song of contentment. Strange you have not heard this before, for the wind has been there all the afternoon. But it is toward nightfall that the cove wakes up and you hear many lisping elfin sounds that you have never noticed during the mid-afternoon heat. You hear the sedges talking in the undulations now. You did not hear them before, yet the undulations have been gliding dreamily among the sedges all day. 


\section{THE FROG RENDEZVOUS}

The pasture birds are waking up their preludes of evensong, and the sun across the cove to the west is glorifying all the quivering canopy of green leaves through which it shines with a luminous, diaphanous quality which makes magic all along that side of the cove.

You are on the borderland between the clear definition of reality and the mystic haze of nightfall. To the west, looking away from the glow, all is gently but clearly defined; to the east, looking into the golden rose of the sunset through the shimmering illusion of leaves, lies the pathway to the land that the king's son saw in the Arabian Night's tale.

The nightly entertainment, the evening minstrel show, is about to begin in the cove, an entertainment in which the frogs are the minstrels, an all star per- 


\section{WILD PASTURES}

formance, for every one of them is capable of being an end man or interlocutor or soloist as the case may require.

Already the audience is beginning to gather. First comes a gray squirrel scratching down a maple trunk, his strong clawed hind feet digging into the bark and holding him wherever he wishes them to, as if he were an inverted lineman. Suddenly he sights the canoe and its occupant and-blows up. Nothing else will express his sudden outpouring of scolding and denunciation of this creature that has usurped a front seat. The sounds burst out of him like the escaping steam from a great mogul engine waiting on a siding for its freight, and he quivers from head to foot, like the engine, with the intensity of the ebullition. Suddenly there is a "quawk!" directly over his head, a single cry shot 


\section{THE FROG RENDEZVOUS}

out from the catarrhal throat of a night heron that is just sailing down. The gray squirrel shoots three feet into the air, lands on another maple, flashes up a birch and goes crashing through the birch tops off into the woods, where you faintly hear him jawing still. The night heron whirls with a great flapping and puts to sea with more quawks of alarm. But these two were not especially wanted at the concert. The night heron particularly is an unlovely bird in appearance, voice, and manner. The skippers and the lucky bugs crowd in together, each among its kind, close to the reedy margin, to be as near the performers as possible, and behold, there come sailing in from sea tiny argosies of dainty people, the loveliest free swimmers of the pond. Golden heads nodding in gracious recognition, they come, 


\section{WILD PASTURES}

slender bodied and graceful, trailing long robes of filmy lace beneath them in the water.

The botanists, who shall be hung some day for their literalness, have named these lovely denizens of the cove bladderworts, or Utricularia, if you wish the Latin form, because they float on their air-inflated leaves and trail their roots beneath them, free in the water, scorning the contaminating touch of earth. The off-shore wind of noon had sailed these out well beyond the mouth of the cove, now the evening breeze is bringing them in again for the concert.

They should have been named after some dainty lady of the old Greek mythology, some fair sailor lass who crossed the wake of Ulysses, perchance, and lingers on placid seas waiting his return to this day, for you will see their 


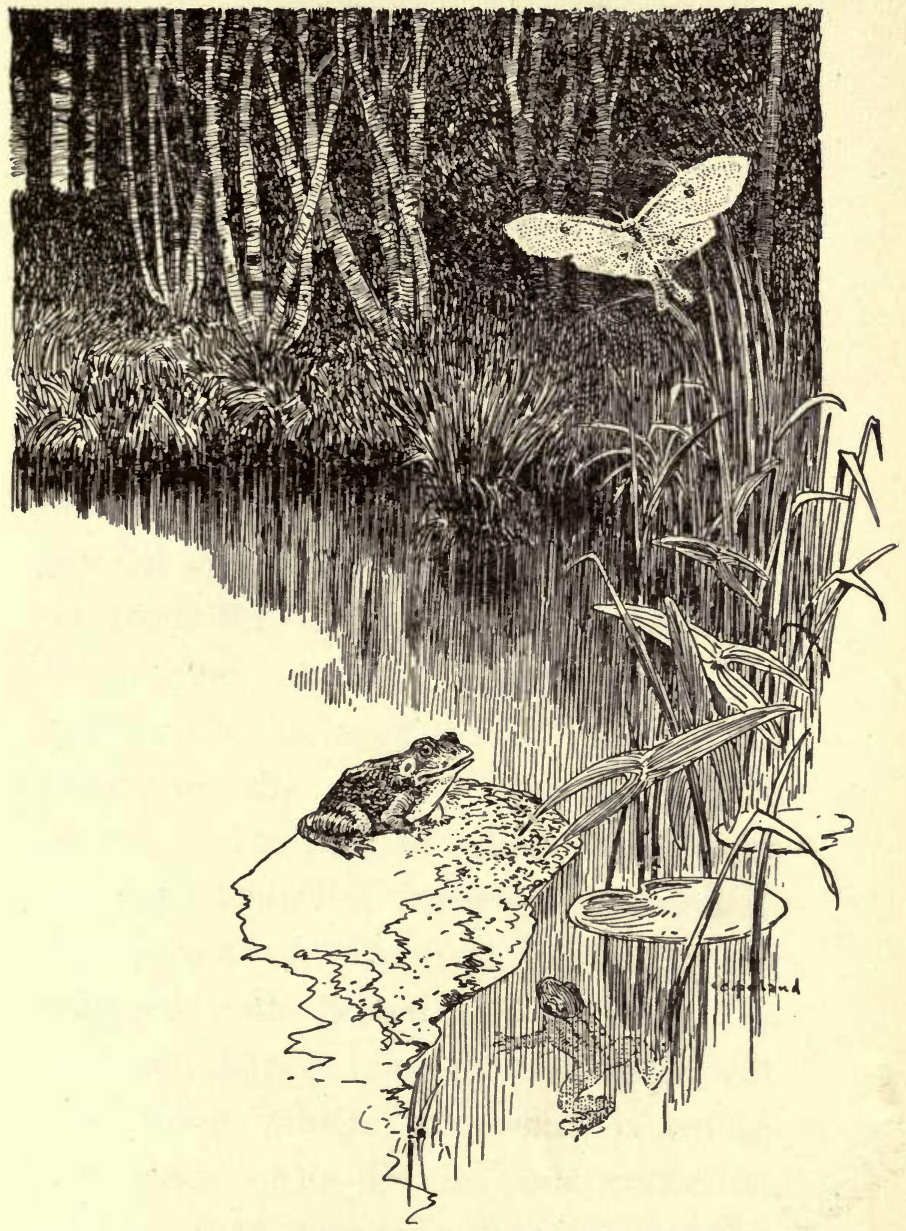

Out from among the birches she sails gracefully, a veritable queen of the fairies 



\section{THE FROG RENDEZVOUS}

golden heads nodding along on the little waves of the cove all summer.

These are the patricians of the concert. There is a great tuning of instruments going on already and a trying out of voices, yet for some reason there is delay. Then comes the queen herself. The golden shimmer on the eastern shore has faded and dusk dances up from the undergrowth on the west. It is time, and out from among the birches she sails gracefully, a veritable queen of the fairies, clad in ostrich plumes and softest of white velvet, with the most beautiful trailing and undulating opera cloak of softest, delicate green, trimmed with brown and white. You may call her a luna moth if you will. The thing which somewhat resembles her, stuck on a pin in your collection, may be that, but this graceful, soaring 


\section{WILD PASTURES}

creature, pulsing and quivering with life, floating through perfumed dusk, is the queen of the fairies - no less.

Her arrival is a signal for the olio to begin. Then, indeed, you learn the astonishing number and variety of the frog performers within the cove. The basso profundos sing "Ah-r-h-u-m-m". with amazing gusto. Surely that waiter frog has got over his fright and brought it in quantity. " $\mathrm{T}$-u-g-gs" resound all about like the rattle of a drum corps. There are altos whose voices sound like rasping a stick cheerfully on a picket fence, others whose strain hath a dying fall of internal agony outwardly expressed. A lone belated hyla pipes his plaintive soprano, but the tenors are the strongest of all. The tree toad flutes a fluttering, liquid tremolo, and the toad, the common toad, sits on the grassy 


\section{THE FROG RENDEZVOUS}

margin and swells his throat and sings "Wha-a-a-a-" in long-drawn, dreamy cadence.

You may imitate this sound after a fashion if you wish. Purse your lips and say the French "Eu" in a long drawl once or twice, then the next time you do it whistle at the same time. You will have a very tolerable imitation of this dreamy note. It invites to slumber and it is time to paddle home, for the dusk has deepened to darkness and there is little more for you to see in the cove. 

A BUTTERFLY CHASE 



\section{A BUTTERFLY CHASE}

I $\mathrm{T}$ was a great purple butterfly which led me over the brow of the hill, one of the "white admirals," curiously enough so called, though this one had but four minute spots of white on him near the tips of his wings. Some members of his genus have a right to the name for they have broad bands of white across all four wings, but this one, the Basilarchia astyanax, is a black sheep.

Nevertheless he is a beautiful creature, well worth following under any circumstances to note the ease and sureness of his floating flight and admire the beauty of his velvety rufous-black, shoaling into lustrous blue in the rounded crenulations of the after wings. This 


\section{WILD PASTURES}

one I thought worth following for another reason, however, for he seemed to have something on his mind. Not that his flight was direct. A bird with something to do goes to his work in a straight line; but a butterfly must dance along, ev̀en if it were to a funeral in the family. And yet with all this my blue and rufous-black white admiral carried in his dancing progress something which told me he was troubled and led me to follow him over the brow of the hill.

The hill itself is worth noting. Here the glaciers which some thousands of years ago planed off the rougher surface of eastern New England dropped their chips in a vast terminal moraine of sand and gravel, whose northern declivity is so steep that you may throw a stone from its rim to the top of a 


\section{A BUTTERFLY CHASE}

pine growing on the level, eighty or ninety feet below. I know many terminal moraines in New England; but I know no other at once so high and so abrupt in its declivity. A few rods back from its summit the trolley car clangs incessantly, and the speed-mad automobilist tears hooting through.

Along the crest, in spite of this, sleep peacefully the forefathers of the hamlet. I like to feel that they neither note nor heed the uproar of the highway; that they now and then cock a pleased ear to the rumble of a passing hay-cart or the jog of a farmer's horse, but that the bedlam of modern hurry whangs by them unperceived. Rather they turn their faces to the sough of the summer winds in the century-old pines which shade the steep and sleep on, happy in the benediction that descends from the spreading 


\section{WILD PASTURES}

branches. Wonderful pines, these, so shading the whole declivity that not more than a dapple of sunlight has touched the ground beneath them for a century.

Here the hepatica finds the cool, dry seclusion that it loves and lifts shy blue eyes to you while yet the winter ice nestles beside it among the pine roots. Here while the July sun distills pitchy aroma from the great trees the partridge berry carpets favored spots with the rich green of its little round leaves, - leaves no bigger than the pink nail of your sweetheart's little finger, a green figured with the scarlet of last year's berries and the white of its wee starry twin flowers. Here, too, in July the pyrola lifts its spike of bells like a woodland lily-of-thevalley and the pipsissewa shows its waxy flowers to the questing bee. 


\section{A BUTTERFLY CHASE}

A butterfly, especially a large butterfly, rarely bothers with these low-growing herbs, though each has its own delicious fragrance - and a butterfly's scent is keen. So my black white admiral alternately danced and soared on down through the richly perfumed areas of the wood while I plunged eagerly after, glissading the needle-carpeted slope, making station from trunk to trunk lest a too headlong flight plunge me to oblivion in what I knew was at the foot of the hill.

Without, the perfervid July sun beat upon the landscape till the dust of its concussion rose in a blue haze that loomed the near-by hills into misty mountain tops and glamoured the whole world with tropical illusion. To our hard-cornered, clear-cut New England it is the midsummer which brings the 


\section{WILD PASTURES}

atmosphere of romance. The swoon of Arabian Nights is upon the landscape, and it is through such heat and through such misty evasion that the Caliph of Bagdad was accustomed to set forth incognito to meet strange adventures.

At the foot of the hill, almost at the borderland which separates this underpine world from another far different, the resinous air is shut in like the genie in the bottle. You feel the oppression of its restraint and wonder, if like the fisherman you might uncork it, if it would loom aloft in a dense cloud that would speak to you in a mighty voice. Here my butterfly paused for the first time and lighted upon the trunk of a pine, head high.

Quietly I drew near. His wings were rising and falling in rhythmic uncon76 


\section{A BUTTERFLY CHASE}

scious motion that was tremulous with what seemed eagerness. One of them, I noted, had a little triangular bit snipped out of it with a clean cut. Some insecteating bird had snapped at him not long before, and he had come within a half inch of death. Yet this did not trouble him; very likely he never knew it. It was something else which absorbed him so that he took no notice of my close approach. And now I could see that his proboscis was uncoiled and apparently he was eating rapidly. Now the proboscis of any butterfly is simply a double-barrelled tube through which he sucks honey or other moist nutriment. That a Basilarchia astyanax, or any other butterfly for that matter, should be able to draw nourishment from the dry, rough bark of a pine-tree was sufficient : cause for astonishment, and I 


\section{WILD PASTURES}

drew eagerly nearer to see what he was getting.

It was a humid day and I was thirsty myself. What woodland brew could be on tap here? In Ireland it used to be true that the Leprachauns, the little men of the hedge, could make good beer of heath, and if you could only catch and hold one he would tell you how. Here might be a similar chance. My nose was within six inches of the white admiral's now and my eyes were bulging out with surprise as much as his do naturally, for behold he had what butterfly never had before, - a little red tongue on the tip of his proboscis, and with it he was nervously licking the bark in its roughest places as hard as he could.

I might have seen more had not my foot slipped on the glossy pine needles, and while I clutched the trunk of the 78 


\section{A BUTTERFLY CHASE}

pine to save myself the butterfly danced away, thinking, I dare say, that I was an abnormally developed wood peewee and had just missed getting him for luncheon. Evidently the south wind had blown up from the gulf more than an Arabian Night's atmosphere; it had sent along portions of the fauna as well. A butterfly with a tongue on the end of his proboscis belongs in the land where rocs pick up elephants in their talons and soar away with them!

Eagerly I sought to follow my Basilarchia astyanax and learn more, but it was not so easy. To follow his flight without care as to the setting of my feet might well be to reach a country undiscovered indeed, for from the very bottom of the northern declivity of the terminal moraine well the springs of the fountain head, and out across these 


\section{WILD PASTURES}

he lightly floated, toward the sphagnumbottom pasture swamp beyond.

I suppose it is well settled, geologically, that a river of pure water flows from some distant northern point, Labrador perhaps, under the eastern portion of Massachusetts. Driven wells find this water almost everywhere. In places it rises to the surface in clear ponds which have no apparent inlet, and from which little water flows, but which are clear and sparkling at a good level the year round. Houghton's Pond, in the Blue Hill Reservation, is one of these nearest Boston. Walden Pond is another, and there are plenty more.

In other places still the water boils out of springs through quicksands of unknown depths, flowing in clear streams through surrounding swamps 80 


\section{A BUTTERFLY CHASE}

where trees have made firm ground alternating with bits of quaking bog and open pools, where a misstep will drop you over your head in a clinging mud that never gives up what it once gets.

Such is the fountain head, and you would know you were coming to it of a hot day even were your eyes shut, for the ice-cold water makes its own atmosphere. We read of bodies of ice that have lasted since the glacial age buried under these terminal moraines whence well such cooling springs; I do not know about the ice, but I can testify to the cold, sparkling water and the grateful atmosphere which it disseminates on these our Arabian days. Yet you must mark well your going. Just under the -slope the water boils up through fine sand that dances in the up current. A few feet farther down it 


\section{WILD PASTURES}

wells more silently, and the decayed vegetation of centuries has made a mud bank over the quicksand. You may sink to the knee here and find bottom. A few steps farther on you may drive a twenty-foot pole down through mud and sand and find nothing to obstruct it.

Yet Nature always provides the remedy. Mosses and swamp grass have grown on the surface of this liquid mud and alders and swamp maple have rooted in these and encouraged wild rose and elder and many another shrub, till their intertwined roots have formed a surface which is in part safe to the foot. And here is a world of itself in this hidden pasture corner, for here linger the trout and the watercress, and many another shy woodland thing, driven to bay by the encroachments of surrounding civilization. 


\section{A BUTTERFLY CHASE}

In early July you will find the watercress in bloom in the open pools, surrounded by quaking bog and alder shade. Toward this my butterfly had gone, and I followed, balancing warily from clump to clump in the grateful coolness, testing each foothold lest it drop me into the clinging depths below whence nothing but a derrick might lift me. The arethusa, daintiest of orchids, nodded its pink head at me from the quaking sphagnum, daintily bowing me on, but I paused a moment.

In the water right between my feet was a spotted turtle that had just captured an appetizing, but by no means dainty morsel. This was a terrapinlike bug that was more than a mouthful. His body, indeed, was already out of sight, but claw-like legs protruded from both sides of that isosceles tri- 


\section{WILD PASTURES}

angle which a turtle's mouth makes when it is closed, and waved a frantic farewell to the passing under-water world. The turtle was a long time in masticating his terrapin, but it was a happy time. His whole body blinked contentedly, and he waved his forelegs with a caressing out-push, a motion exactly like that of a child at the breast. Then he wagged his head solemnly from side to side as a wise turtle might who feels that such good lunches are put up by fate only for the knowing ones of this watery world, and pushed himself half way under the roots of a tussock for a nap. Soon the nether half circle of his shell was motionless, with his hind legs drawn up within. Only his little spike tail protruded, waving to a wee passing trout the news that the millennium was at hand, and 


\section{A BUTTERFLY CHASE}

the turtle and the bug-terrapin had lain down together in peace and prosperity, with the bug-terrapin inside.

I looked up for the butterfly. $\mathrm{He}$ was nowhere to be seen. Yet my trip - was to be worth while, for right in front of me was an open pool surrounded by a quaking bog, a pool twenty feet across packed almost solid with the white panicled heads of watercress blooms in which swarmed a myriad of bees. Their drone was like that at the front door of a hive on a hot July day, yet it was not a monotone as that is. It was rather like a grand chorus singing many parts, for these were all wildwood bees of a dozen varieties. There was not a hive tender among them.

Lifting my admiring gaze from the pool with its white panicles and $85^{\circ}$ 


\section{WILD PASTURES}

swarming bees I saw further beauty beyond. On. firmer ground nestling lovingly against an old chestnut post was a great, glorious spike of habenaria, the purple-fringed orchis. It is not uncommon, the habenaria, in peaty meadows, but no man sees it for the first time in the season without a great glow of delight, and I hastened over to give it nearer greeting. Just as I reached it the butterfly came dancing up, but not to sip the sweets of the wonderful great orchid. Instead he lighted, right under my nose, on the roughest part of the old fence post and began to lick this as he had the pine trunk.

I watched him again, hearing subconsciously the voice of a great crested flycatcher over on a near-by tree, crying "Grief," "Grief." A moment and the little red tongue which I had noted 


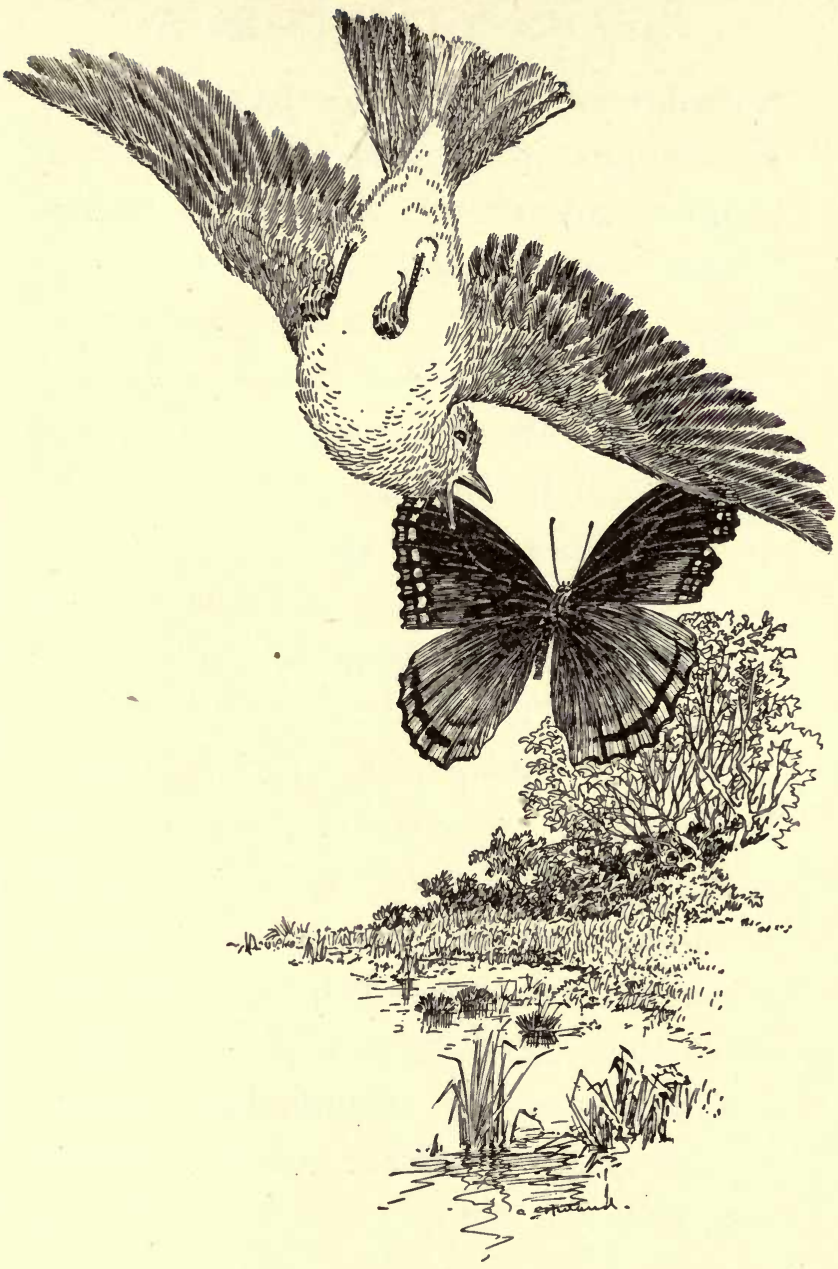

There was the swish of wings, the snip-snap of a bird's beak, and it was all over 



\section{A BUTTERFLY CHASE}

before seemed to catch on the roughest part of the old fence post, and with a sudden scrape the Basilarchia scraped it off. I looked in amaze, for now I saw what it was. From the honey heart of some flower a little red worm had become attached to the tip of the butterfly's proboscis, and all this licking of rough surfaces had been merely to get rid of him.

Up into the bright sunshine danced my black white admiral. There was the swish of wings, the snip-snip of a bird's beak, and it was all over. The cry of the great crested flycatcher had been a prophecy indeed, and the white admiral had danced blithely out of existence.

But the equatorial haze had more tropical enchantment in store, for the midday sun was suddenly wiped out by an ominous figure. Some one had un- 


\section{WILD PASTURES}

corked that bottle which held the heat genie confined, and he was looming from a black nimbus below into white piles of cumulus at the zenith. His eyes flashed red lightnings and he spoke in thunder tones. Somewhere over yonder I heard the great crested flycatcher crying "Grief," "Grief," again. It might be my turn next, and I patted the great orchid good-by and tiptoed through the sphagnum and climbed the hill again. It had been a brief but pleasant trip. A butterfly that found a tongue and a turtle that ate terrapin with a happy smile may belong with the genie in the Arabian Nights, or with Alice in Wonderland, or both. I know that I found them at the fountain head, under the grove of immemorial pines, below the brow of the terminal moraine where sleep the fathers of the hamlet. 


\section{DOWN STREAM}





\section{DOWN STREAM}

IF you have ever known fishing, real fishing, not the guide-book kind, where you "whip" streams for fancy fish that bite mainly in fancy - there will come a day in late July when it will be necessary for you to go down stream. The excessive heat and humidity which has been killing you off by inches and other people by wholesale for weeks will suddenly vanish before a cool, dry northwester, a gladsome reminder to the New Englander that there is such a thing as winter after all; thank Heaven!

- You know that the drought diminished waters still fizz out from under 9I 


\section{WILD PASTURES}

the dam and purl into the pool below the roadside where the sunfish congregate under the water weeds. Beyond this they prattle down the meadow under banks where the hardhack stands pink and prim, where the meadow-sweet loves the stream so much that it bends toward it and half caresses, and where the meadow grasses in complete abandonment whisper of it in every wind and bend down and surreptitiously kiss it as it dimples by. Farther down where the woodland maples troop up to meet it and the willows sit and bathe pink toes in the current is the big rock, under which the current has dug a sandy cave in which linger big yellow perch, ready to rush out and snatch the worm that comes floating down stream. Here you will hesitate but finally pass on, for there is a lure 


\section{DOWN STREAM}

which you cannot withstand in the deep pool farther down.

Because you are wise with the remembered wisdom of boyhood, you have left at home the expensive rod and reel. Just back from the swamp edge is a birch jungle where young trees stand as thick as canes in a Cuban brake. Here you find your pole; as large as your thumb at the butt, tapering, straight, clean and strong, fifteen feet to the tip. Cut it and trim the limbs from it and bend to it your ten feet of stout line at the end of which is a hook whose curve is as big as that of your little finger nail. A cork that would fit a quart bottle will fit your line if you gash it with your pocket knife and slip the line in the gash. It will hold wherever you put it, yet you may slide it up and down at will. For the pool 


\section{WILD PASTURES}

you should put it three feet from your hook, for you will wish to "sink" that deep. Wind a wee bit of lead about your line an inch above the hook, then pull out your bait box and select a fat angle-worm. Break him in two in the middle and string him on the hook so that the point is just inside the tip of his nose. Now you are ready for what adventure may lurk under the bubbly foam of the surface.

A willow and a maple lean together in loving embrace over the entrance to the deep pool. Above, their arms stretch toward one another and intertwine; below, their roots meet under water and sway down stream, forming a slippery steep down which the amber yellow water, singing a happy little song to itself, coasts into the amber black depths of the pool. Black alders stand conl- 


\section{DOWN STREAM}

ing their feet all about the edge. Crowding them into the water are the great oaks and maples whose limbs yearn above the pool till they shut out the sun. Along one side the current has cut deep to the rough rocks and the water flows black and swift. On the other the back-wash circles leisurely and the bottom shallows to a bank of sand where the sunfish build their nests and the fresh-water clams burrow and put up suppliant mouths to the foodbearing current. Inshore it lifts to a sand bar, where you may stand and swing your pole without interference from the surrounding trees.

All day long the brook sings itself to sleep as it slips down the slide into the slumberous depths of the pool. All day long the vivid green dragon-flies flutter by with vivid black wings to bring 


\section{WILD PASTURES}

luck to your fishing, and the red-eyed vireo pipes his sleepy note in the trees above. And all day long you shall catch fish if you will but bait your hook and drop it in. First you will thin out the sunfish, for they are the most alert and gamy of all. Talk about trout! You should try landing a half-pound sunfish on a gossamer tackle and a very slender pole. The sunfish is the Lepomis gibbosus of the ichthyologists and is a close relative of the rock bass, and just as game. He has been irreverently dubbed "pumpkin seed" in some places, from his shape, which is that of a pumpkin seed set up on edge. Here in eastern Massachusetts he is just plain "kiver," which is the oldtime uneducated New Englander's pronunciation of the word " cover," given him, no doubt, because he is round and flat. $\mathrm{He}$ is as freckled 


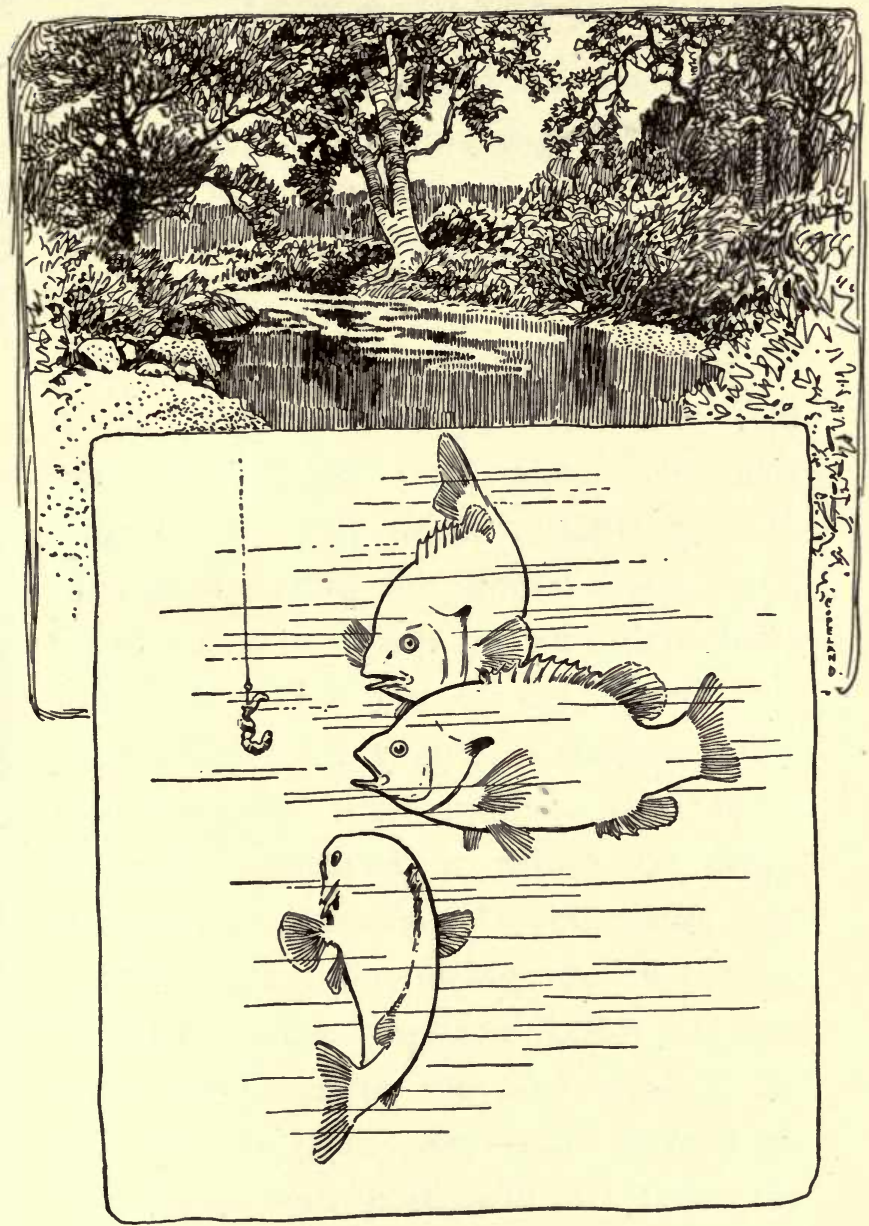

The way of the "kiver" is this. There is a single, snappy, businesslike bob, then another, then three in quick succession 



\section{DOWN STREAM}

as a street urchin and as lively. $\mathrm{He}$ has business with your bait the moment it drops near him, and the bobbing cork will show that it is he by the jaunty vigor of its bobs.

In fact, if you have learned the ways of the down-stream country you will know every fish that takes your bait long before you have brought him to the surface from the amber depths, just by the way in which he bobs that floating cork. The way of the "kiver" is this. There is a single, snappy, business-like bob, then another, then three in quick succession in which he drags the cork half under. If you strike just at the right time during the succession of three, when the line below is taut with the strain of the float against the pull of the fish, you shall have him. Otherwise your cork will lift from the 


\section{WILD PASTURES}

water with a humorous snort and you will hear little trills of derisive laughter in the song of the stream cascading down the willow root chute. It will be safer not to try him on the three bobs, but wait till the cork begins to bore into the water and glide off across stream, showing that the sunfish has made up his mind that it is a worm, a good one, and one that he really wants.

The mother sunfish just at this time of year has her nest in the sand at the upper end of the bar, in shallow water. It is a circular depression which she has scooped out and from which she has carefully removed all pebbles and sticks. Here she has laid her eggs, and here, day and night, she stands guard over them. If any other fish comes along, even of her own kind, she will chase it away with a brustling courage 


\section{DOWN STREAM}

which is like that of a mother hen defending her chicks. So, after you have caught the freelance sunfish of the pool, those which have no family cares, do not drop your bait near her nest, for if you do she will dart out and take it, and it is a pity to have the brook lose her. She has made her nest in the one shallow spot where the bright sunlight plays, and you may see every dapple of her lovely sides as the light glances on them. Her every fin quivers as she floats there, slowly turning from side to side, her bright eyes roving in search of enemies to her offspring. She is a whole torpedo boat of mother love and pent-up energy, and so let us leave her, for she makes the whole pool seem homelike and hospitable.

The yellow perch will come next to 


\section{WILD PASTURES}

your hook, his tawny yellow sides marked by bands of dark green, his back a darker green yet, and his fins a rich red. $\mathrm{He}$ is the aristocrat of the pool, his family being one of the very oldest in the fish domesday book. $\mathrm{He}$ lies in deeper water than the sunfish, and his bite varies from a gentle nibble to a good strong succession of pulls which finally end in the cork going down out of sight altogether. Yet when he is at the bait you shall not mistake any motion of that bob for the ones made by the sunfish. The perch has a daintier, more gentlemanly touch. It is sure and strong, but it lacks the roistering vitality of the sunfish. It is an aristocratic bite, and you will recognize it as such without clearly knowing why, - which is proof of his aristocracy. You will recognize it, too, from 100 


\section{DOWN STREAM}

the elegance of his figure and the chaste beauty of his attire. He gleams in the sunlight. His yellow and green markings are as vivid as those of the sunfish, yet arranged in exquisite taste, and he is dapper where the other is bourgeois.

Sink a little deeper now, for it is time you caught horn-pouts. The hornpout is also "bull-head," and, irreverently I fear, " minister," because of the severity of his black attire, which is relieved only by a white vest. But hornpout is the best name, for his horns stick out fierce and straight from either side of his gills like the waxed mustachios of a stage Frenchman. They are sharp as needles and set as firm as daggers in their sockets. When you outrage the dignity of a horn-pout by pulling him out of the water he wag- 


\section{WILD PASTURES}

gles these fins of dagger-bone and makes a peculiar grumbling sound with them. It is as if he said, "What! what! What's all this? Who dares disturb my comfort?" Then when you reach to take him off the hook he flips that nimble black tail of his and jabs his dagger into your hand. It makes an ugly wound, and the boys claim that it conceals venom; a sort of poisoned dagger. The horn-pout bobs your floating cork usually twice or three times, a very different bob from either that of the sunfish or the yellow perch. It is a steady, solid down pull each time, taking the cork half under water. Then he takes hold in earnest, and the float goes steadily down and out, as if this were a matter of no child's play, but meaning something that is solid and substantial on the other end of the line. Often- 


\section{DOWN STREAM}

times this is true indeed, for the blackcoated one may weigh a pound or two and double your birch rod into a good half-circle before he lets go his grip on the water.

When you get down to the hornpouts you have fishing indeed, but all the time the climax of your day's career is lurking down in the cavernous depths where the stream has gullied far beneath the ledge, for there, as thick as your wrist and three feet long, weighing a pound to the foot of solid white flesh and muscle, is an eel.

The eel is the strange misanthrope of the brooks and fresh-water ponds. You may peer into the sunlit shallows and see the other fishes at their work or play. They are companionable. If you will live on the pond edge you may train the minnows, the sunfish, the yel- 


\section{WILD PASTURES}

low perch even, to come up and eat out of your hand. I have watched a big horn-pout lumbering about in the shady depths for an hour and seen him carefully inspect a hookless worm which I had dropped to him, before he ate it, noting with glee the gravity and selfimportance with which he finally decided that it was all right and that he would confer a favor upon it by swallowing it whole. Yet never once have I seen or laid hands on an eel in fresh water. There he goes his own mysterious way among the rock crevices and along the mud of the ultimate depths. The other fishes of the brook travel in schools; he goes alone. They were spawned up stream; he was born on the sands of the fishing banks, a hundred miles off shore. He came upstream as a young eel squirming through dams that shut IO4 


\section{DOWN STREAM}

out other fishes. When the time comes for him to go back he will go back the same way, waxed fat indeed, but still unseen, devious, self-possessed, and uncannily shrewd.

That he may live to go back he inspects carefully the worms which may drop into the cool shadows where he lurks. When he is about to take your bait you need to be keen to know what is going on, for he suspects you, and your least untoward motion of rod or line will cause him to slip back like a shadow into his cavern, and there will be no bite from him on that hook after that. You will say that it cannot possibly be a bite; the bob simply stops and the hook has no doubt caught on a snag on bottom. If you are not wise enough to know better you will pull up here lest you lose your hook, and in so doing you 


\section{WILD PASTURES}

will lose your eel, for he is simply testing you. He has hold of the very bottom of that hook, below point and barb, and if you pull you pull it out of his mouth without hooking him. Then in cynical glee he'll wag himself deeper into his cavern beneath the stones, and that is the last of him. You may fish the pool for a week before he will forget his caution and try another angle-worm. If, however, nothing rouses his suspicions the bob will gradually sink lower till it is more than half submerged, hang there for a little, give another sag downward, and so by degrees be drawn cautiously under. Your eel is cannily carrying the hook down into his cavern, where he may finish his meal at leisure. Now is the crucial moment. He must not be allowed to get in among the stones, for even if your strike hooks him he will 


\section{DOWN STREAM}

twist himself desperately around them and then twist the hook out. A steady quick pull and you feel him on. Then indeed you "give him the butt," as the fly fishermen say gloryingly. Your lithe birch rod bends in your hands till the tip is near your wrist as you lean desperately back with all your strength. The hold of a three-foot eel on the water is tremendous. Until he tires a bit it is almost as good as yours on the birch pole, but steadily, inch by inch, you draw him away out into the pool, where the fight is a fair one. Now his head is above water and his great lithe body whirls like a propeller beneath. Again look out; for when he leaves the water it will be as if he shot out, and you are liable to go with him, backward into the bushes, where he will tie your line into ten thousand knots, break out the 


\section{WILD PASTURES}

hook, and run for the brook as a snake might.

At the moment he leaves the surface you slow up. Up into the air he shoots and drops till his tail welts the ground at your feet. Here let him wriggle at the end of the taut line while you break a stout alder switch with one hand, and as you drop him to earth belabor him with it. This will stun him quicker than anything else, and you may then deal with him as you will, only be quick about it, for he is very tenacious of life.

Then, if you are a true fisherman, you will wind up what line is left you and go your way, for the pool has no more foemen worthy of your steel. There will be but one eel to a pool, and to go on catching sunfish would be insipid indeed. 


\section{BROOK MAGIC}





\section{BROOK MAGIC}

B ROOK magic does not begin until you have passed the deep fishing-pool and traversed the reedy meadow where the flagroot loves to go swimming and the muskrats come to spice their midnight lunches with its pungent root and pile the broad flags for winter nests. You may, if you are alert, feel a touch of its witchery as you wind among the rocks and black alders of the level swamp beyond, for here the ostrichfeather fern lifts its regal plumes as high as your head, and if by any chance you duck under these you have been near the portals of a world where sorcery is rife, for fern seed has a mysterious power of its own, and the ferns of 


\section{WILD PASTURES}

the alder swamp are decorations on the road to the realm of the witch-hazel, where all sorts of strange things may come to pass.

The ferns and the witch-hazel are themselves mysterious and promoters of mystery, and it is hard to tell which leads in waywardness and subornation of sorcery. The ferns are the lingering representatives of an elder world, - a world that was old before the first pine dropped its cones or the leaves of the first deciduous tree fell on the first greensward. Their ways are not the ways of modern plant life.

Take the cinnamon fern, for instance, one of the commonest of our woods. It grows up each spring like a tender and succulent herb, to wither and die down in the fall as the grass does. But take a spade into the woods with you and try 


\section{BROOK MAGIC}

to transplant a good-sized cinnamon fern. You will fail, unless you have brought an axe along too, for the seemingly herbaceous plant has an underground trunk, sometimes two or three feet in diameter, almost as solid and firm in texture as that of a tree.

The fern shows no blossom to the world of butterfly or moth, no fruit for the delectation of fox or field mouse. The curious little dots growing along the margins of the leaves, which we call "fern seed" by courtesy, grow no fern when planted. They simply grow a little primitive leaf form which curiously imitates a blossom in its functions and produces a new fern.

But the witch-hazel is stranger yet in its ways. In the spring, when it should by all tokens of the plant world be putting out blossoms, it is busy growing 


\section{WILD PASTURES}

nuts which are the product of last year's blossoms. Then in the late autumn, even November, you will find it in bloom, twisting yellow petal fingers in mourning at the fall of its own leaves.

Pluck one of the nuts of a midsummer evening and look it intently in the face. Note the little shrewd pig eyes of the witch far ingrown in it, the funny shrewish tip-tilted nose, the puffy cheeks and eyelids. See that slender horn in the forehead, the sure mark of the witch. No wonder that it has the name witch-hazel with such ways and such faces growing all over it at a time when most other trees and shrubs have but finished blossoming. But if you want further proof that this shrub harbors witches you need but to examine its oval, wavy-toothed leaves just at this 


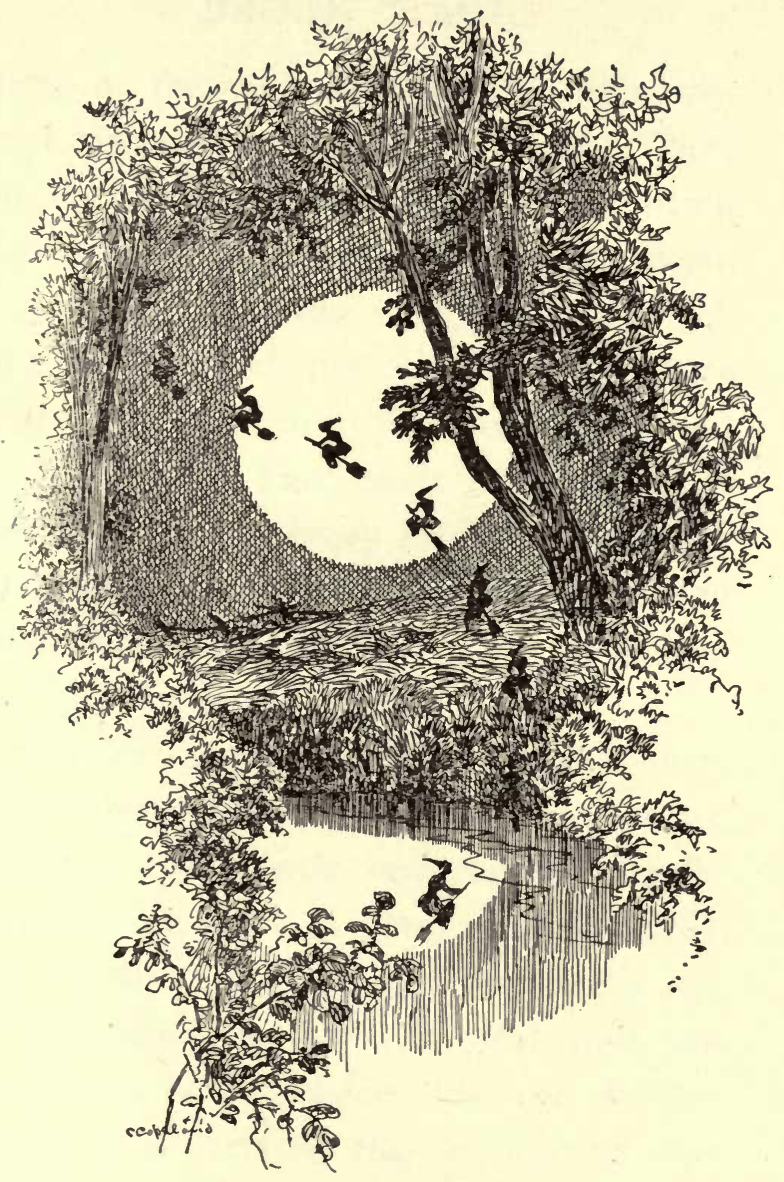

That such things are not seen oftener is simply because people are dull and go to bed instead of sitting out under the witch-hazel at midnight of a full moon 



\section{BROOK MAGIC}

time of the year and see the little conical red witch-caps hung on them. There need be but little doubt that, sitting under it at midnight of a full moon, you may see the witch faces detach themselves from the limbs, put on these red caps and sail off across the great yellow disk. That such things are not seen oftener is simply because people are dull and go to bed instead of sitting out under the witch-hazel at midnight of a full moon.

To be sure there are scientific men, gray-bearded entomologists, who will tell us that these little red caps are galls, the rearing-place of plant aphids, caused by the laying of the mother insect's egg within the tissue of the leaf, but one might as well believe that the witches hang their hats on the witch-hazel over night as to believe that the laying of a 


\section{WILD PASTURES}

minute egg in the tissue of a leaf could cause the plant to grow a witch hat.

No doubt these same wise men would explain to you that it is not possible to become invisible by sprinkling fern seed on. your head during the dark of the moon and saying the right words, but did one of them ever try it?

It is appropriate that the witch-hazel should shade the portals through which the brook enters the glen at the foot of the pasture, for the path here enters you into a world of witchery where the glamour of the place will hold you long of a summer afternoon.

At the foot of the glen an ancient mill-dam once blocked the free passage of the water and a mill-wheel vexed its current. Now only the rude embankment remains with half-century old hickories and maples growing on it, arching II6 


\section{BROOK MAGIC}

in and shading the glen with their imbricated branches. No rust of millwheel, no trace of building remains, and the very tradition of the mill and its owners is gone. No one to-day knows whether it ground corn or sawed boards for the pioneer who built it, who laid the sill of its dam so firm and level that the wear of two centuries of swift water has not entirely obliterated it. At the very bottom of the glen it forms a shallow pool where brook magic and witchhazel glamour shall show you many midsummer fantasies if you will but look for them.

It was in the glen that I found the first real relief from the heat of midday. The grasses of the sun-parched pasture had crisped under foot and broken off, so dry were they, all the way down to the sweet-flag meadow. Here the brook 


\section{WILD PASTÛRES}

water keeps all growing things lush and green, but the glare of the sun is only the more intense. It follows you into the alder swamp, and you may sit under the arching fronds of the ostrich-plume ferns in vain.

But after you have scrambled through them and ducked under the mock benediction of the witch-hazel limbs that stretch above your head while the witchhazel faces grin a cynical "Bless you, my child," you feel that you are willing to take your chances with swamp witchery and brook magic. For in the glen cool waters crisp over cold stones and the breeze sighs up stream and fans you as you sit on the brink of the pool and lean your head against the ledge from whose crannies drip the fairy fronds of the rock fern.

These are but little fellows of our II8 


\section{BROOK MAGIC}

fern world, and the magic which distills from their fern seed is no doubt less potent than that from greater ferns, but added to the witch-hazel glamour it makes brook magic which will initiate you into many mysteries of the pasture world if you are but patient. Sitting there with the tiny brown spores of the rock fern dripping upon your shoulders with infinitesimal rattle, you seem to see more clearly the glen life and to know the meaning of many sounds hitherto only half understood.

Always there is the sleepy song which the brook sings to itself in summer, a song to which the warble of the vireo in the overhead leafage adds but a dreamy staccato. But if you listen through this you shall presently hear the water goblins grumbling to themselves in their abodes under flat stones. 


\section{WILD PASTURES}

They are old and grumpy, these water goblins, and they never cease to mumble to themselves about their troubles.

Very likely they complain incessantly because they are hungry and the supply of demoiselle nymphs is running short. There are plenty of demoiselles, flitting back and forth across the pools on glittering black wings, which they fold closely to their iridescent green bodies when they light. They are such ladylike dragon-flies that it is no wonder that the name "demoiselle," which French scientists with admirable gallantry have given them, has stuck. With all their ladylike short and modest flights and the saintly way in which they fold their wings when they light on some leaf beside the pool, a folding as of hands in prayer, the demoiselles are dragon-flies, and each prayer may well 


\section{BROOK MAGIC}

be for the soul of some midge or other wee insect captured in the short flight.

The true dragon-fly - the one which rests with wings widespread - hunts like a hawk, but the demoiselles seem to take their prey with a gentle grace and charm of manner which ought to make the midge's last moments his happiest ones. I always suspect them of folding him in a perfumed napkin and eating him with salad dressing and a spoon after they get back to their boudoir, but I cannot prove this any more than I can that it is really a water goblin that grumbles under the flat stone.

Many a time I have turned the stones over suddenly, but I never yet was quick enough to surprise the goblin. I have found him there, mind you, but never in his true shape. Always he has man- 


\section{WILD PASTURES}

aged to transform himself into something different, - perhaps into a spotted turtle or a grouchy horn-pout. I have even known him to turn into an ugly, manylegged helgramite worm, not having time to make the more reputable transformation. It is hard to catch a grumbling goblin asleep, especially in a pool below the witch-hazels, where the brook magic is strong.

It is easier to see the demoiselle nymphs. They are not very beautiful or seemingly very savory, and if the water goblins do eat them it is no wonder they grumble. You may have seen a hawk-like dragon-fly skimming about over an open pool dip in swallow fashion to the surface. These sudden and repeated dips are not for a bath nor yet for a drink. What you see is a female dragon-fly laying eggs which shall later 


\section{BROOK MAGIC}

hatch and become under-water nymphs, the larvæ of the dragon-fly. But the demoiselles, still rightly named, do nothing so brazen as that. Instead, they pick out some nodding water weed, fold their wings a little more tightly to their iridescent bodies and crawl down it into the water. Here, in proper seclusion beneath the surface, they pierce the reed's stem with keen ovipositor and lay their eggs. Then they saunter forth again and discreetly eat more midges with salad dressing and a spoon.

If you look closely among the water weeds in the transparent water at the pool margin you may see the demoiselle nymphs crawling about, breathing through feathers in their tails, and scooping up food with a big shovel which sticks out under their chins. They show little traces of their coming beauty. 


\section{WILD PASTURES}

It is the awkward age of the demoiselle, and I fancy each is right glad to do up the hair, get into long black skirts with iridescent green bodices, and join the afternoon tea flitters.

What the magic is in the brook, whereby these strange, awkward, crawling creatures, living beneath the water, some day crawl up the stem of a water weed, burst, stretch their wings and fly away the saintly and demure demoiselles of the pool, I do not know - whether it be distilled from the witch-hazel by the summer sun, or whether it slips more mysteriously from beneath the breastplate of the spore of the polypody growing just above my head in the rock crevice. It must be the same magic whereby the many-legged, crawling helgramite worm, after living that sort of life sometimes for several years, one 


\section{BROOK MAGIC}

day crawls ashore, goes to sleep beneath a stone, and in another month wakes up and finds himself a Corydalis comuta, a three-inch-long bug with extraordinary wings and great horns, - a bug that might well make one of those witches, met face to face on the moon's disk, shriek and fall off her broomstick. If he can be that thing, changed from a helgramite worm, why can he not be a helgramite worm, changed from the water goblin which you can hear grumbling beneath the flat stone at the entrance to the pool beneath the witchhazels?

The answer is to be found neither in the rhyme of the poet nor in the reason of the scientific man.

Musing on these things I suddenly sat up from my quiet seat beneath the rock ferns, for more magic yet was being dis- 


\section{WILD PASTURES}

played before my eyes. Over on the further side, in the shallow eddy, the pool was troubled a second, then there rose from it a wee sunfish, not more than three inches long, rose from it tail first and began balancing across the pool surface toward me, on his head. His tail quivered in the air, and I could see his freckles growing in the yellow transparency of his skin, yet, though I watched with wide eyes, he was two-thirds the way across the pool toward me before I noticed beneath him the tip of the nose and the wicked little dark eye of a water snake. At sight of him the demoiselles should have shrieked and flown away, but they made no move. I, however, indignant, arose, and seizing broken fragments of rock was about to lacerate him and loose his prey when I quite suddenly thought better of it. Had not I 26 


\section{BROOK MAGIC}

I a few days before come down stream to the deep pool above and carried off a string of perch, sunfish, pouts, and an eel? Had not the water snake also a right to his dinner?

I dropped my rock fragments, but there was no longer pleasure in waiting to woo the demure coquetry of the demoiselles. The serpent had entered Eden and the man was driven forth. I lingered only long enough to see the grace and strength of the snake as he glided over the sill of the old dam, now black and sinuous, now giving me a glimpse of the vivid red of the under parts of his body, but always keeping his grip secure on the little sunfish whom he was taking away to luncheon with him.

I climbed out of the glen, glad to go for once, but at the top of the rock 


\section{WILD PASTURES}

where the sunburnt pasture path begins again I was in for another shudder, for here the dragon had entered fairyland. He came, writhing his horrid length along the path, his scales shining in the sun, his great mouth gaping, and up near his abnormally great head two little impotent forelegs wriggling. Who would n't turn and run before such a creature as this? To be sure he was scarce three feet long, and his curiously mottledbrown back was that of the common adder, one of our harmless snakes, though he looks ugly enough to be stuffed with venom. But this great gaping head and the wriggling forelegs; never did flat-head adder have such a front as this!

My compassion for snakes that had a right to their dinner vanished before this creature. It is different when it seems I 28 


\section{BROOK MAGIC}

as if you might be the dinner. Those forelegs beckoned, and how could I tell but, in this land of witch-hazel, fern seed, and brook magic, I might not shrink sufficiently to be taken in by that huge mouth in that misapplied head? Death were better, - that is, death for the dragon, - and I caught up a jagged piece of the top of the glen and hurled it at hini. It struck the beast fair amidships. The dragon whirled and writhed for a second or two and lay motionless, and behold! the head separated from the body and began to limp away. Then first was the spell broken and I saw clearly. It was simply a flat-head adder that had taken a good-sized garden toad for his dinner, had swallowed him whole as far as the forelegs, but failed to engulf these. It was the combination which made the dragon. 


\section{WILD PASTURES}

Somehow I have n't cared for the glen since. The early glamour of brook magic is pleasant, but I fear that, like the hasheesh of the Orient, its end is very bad dreams. 
IN THE PONKAPOAG BOGS 



\section{IN THE PONKAPOAG BOGS}

I DO not find in all my wanderings, afield or afloat, a more quaintly delightful plant than the floating-heart. In my pasture world it grows in one place only, - along the shallow edges of the bogs of Ponkapoag Pond. I think no other pond or stream in this immediate region has it, and so sweetly shy is it that you may pass it year after:year without noting its existence. It waits until the summer has marked its meridian before it ventures to send up its dainty little crêpe de chine petals, each fairy-like bloom appearing for one day only in the very throb of the mottled olive and bronze heart, which is a leaf. The leaf itself is barely an inch across, the ex- 


\section{WILD PASTURES}

quisite bloom less than half that; yet once you know it you love it beyond all other bog plants as being the most fairylike of water-lilies, though it is not a water-lily at all when it comes to botanical classification, being of the gentian family.

However, not to be a water-lily is not so bad if one may be classed with the fringed and closed gentians which are to bloom later on the landward edges of the bog. As the little blossom fades at nightfall, its short stalk curls back beneath the water to ripen the seeds there, hung just beneath the leaf from a peculiar bulb-like nodule just an inch or so down on the petiole. The next morning another wee white bud shoots up in the heart angle of the leaf and opens fragile petals in the sun.

I recall no other plant that sends up 


\section{IN THE PONKAPOAG BOGS}

blooms from the leaf stalk in this way. When the seeds have ripened I suspect the plant of setting this bulb-like nodule free to float away to another shore, take root as a real corm or tuber might, and produce more floating-hearts.

This bog on the westerly shore of Ponkapoag Pond was not long ago made a part of Boston's park system, which thus moves ever sedately toward the Berkshire hills, yet it is a bit of nature as wild and untrammeled as it was in the days when Myles Standish may have looked down upon it from the top of great Blue Hill, as it had stood unchanged in his day for many and many a long century. So I fancy it will remain for centuries to come, for Nature holds her own here well. Indeed, she encroaches, for a bog grows wherever it has free water to grow into. So, after many 


\section{WILD PASTURES}

centuries, frequenters of the Blue Hill Reservation will note a broad expanse of swamp land where once sparkled the waters of this hundred-acre pond. For the way of the bog is this.

All along its under-water front the obscure under-water weeds grow up and die year after year, generation after generation, forming fertile banks of beautiful soft mud, into whose lower depths the great thick rootstocks of the pond-lilies push, and in which the fibrous roots of the tape grass, the fresh-water eel grass, find a hold. The growth and decay of these, with the water shield, with its jelly-protected foliage, the yellow dog-lily, and in lesser depths the bulrush, add to the growing bank as coral insects grow and die in tropic seas, until it is near enough to the surface for the pickerel weed to find roothold. 


\section{IN THE PONKAPOAG BOGS}

Then indeed the bog steps forward with vigor, for the pickerel weed is its firing line. All summer you shall see its blue banners flaunting gayly in the southern breezes, tempting the land-loving bumblebee to sea, calling the honey-bee from the mile-distant hive, and offering rest and luncheon to a myriad lesser insects, all with genial hospitality. Its serried millions in close ranks breast the waves in a broad blue line from one end of the bog to the other, a half-mile or so.

Behind these are shatlow pools, where again you find the white water-lilies. Here they bloom in enormous profusion from late June until early September, reaching their grand climax during late July. On such a day, standing in the boat at the southerly end of the bog, counting those within a given space and multiplying, I estimated that there were 


\section{WILD PASTURES}

ten thousand of the fragrant white blooms in sight. Twice as many more were hidden by bulrush and pickerel weed. On Sundays and holidays boatloads of trolley trippers paddle and push among them and carry them off by the hundred, yet they make no mark on the visible supply. The decay of the leaves and stems of these add to the under-water foothold of the bog, but after all it must be the reedy stems, sagittate leaves, and interwoven roots of the pickerel weed that are its main foundation.

Steadily seaward over the foundation thus laid progresses the long, definite front of the saw-edged marsh grass. Once it interlocks its roots along the mud surface formed for it, it leaves no room for the freer-growing denizens of the shallows. In among the marsh grass grows no flaunting flag of pickerel weed, 


\section{IN THE PONKAPOAG BOGS}

no pure white nymphæa sends forth its rich odor.

Only the bog cranberry may hold its own in any quantity against the throttling squeeze of those grass roots. Where these grow is the high sea of the bog, its waves rising and falling in the free winds. Yet, just as pickerel weed and water-lily give way before the advance of the marsh grass, so it in turn falls on the landward side before the advancing hosts of the swamp.

A steady phalanx of swamp cedars pushes its foothold farther and farther out upon it, year by year, scouting with button bush and black alder and holding every inch that they obtain for it. Now and then something happens to a brief area of marsh grass and cranberries so that their dense packed minions faint and release their root grip on the quak- 


\section{WILD PASTURES}

ing mud. Every such opening is seized by the alder or the button bush, and the cedars follow them; indeed, sometimes the cedars, favored by the right wind or the right bird carriers at seeding time, slip in first, and little island clumps of their dark bronze green stand here and there over against the cadet blue of Blue Hill which hangs like a beautiful dropcurtain always on the westerly sky.

Once, a half century ago or more, a farmer and his men came down from the pastures, and for purposes of their own cut a ditch straight through the middle of the bog to the open water. The hundreds of scrawny night herons, sitting on pale blue eggs in scraggly nests in the cedar swainp must have heard the cedars laugh as this went on. It was the swamp's opportunity. Where the farmer and his men with incredible 


\section{IN THE PONKAPOAG BOGS}

labor cut and tore away the marshgrass roots the cedars planted their seeds, and called upon the alders and the swamp maples and the thoroughwort, the Joe Pye weed, and a host of other good citizens of the swamp, to help them.

So vigorous was the sortie and so well did they hold their ground that you may trace the farmer's wide ditch today only as a causeway down which the swamp has come to build a great wooded area in the midst of the bog, accomplishing in half a century what it might not have done in five times that had it not been for human aid. Thus, slowly as you and I count time, only an inch or two a year perhaps, yet all too rapidly for the joy of future generations, the bog encroaches upon the pond and the swamp follows towards complete possession, which as the centuries 


\section{WILD PASTURES}

go by will make the quaking sphagnum firm meadow land.

For all you and I know, the Metropolitan Park Commission of the year 3908 will be fixing up a second Franklin Field here for the camping ground of visiting Pythians. Meanwhile let us hasten to enjoy our bog and its reedy borders.

It is the home and the occasional resting place of many a wild free creature. Of a clear midsummer evening you may hear the muskrat grubbing roots there, see, perhaps, the moonlight glint on the long $\mathrm{V}$-shaped ripple which he makes as he swims, and hear his snort and splash when he dives at sudden sight of you. You may chance upon a disconsolate bittern sitting clumsily in dumpy patience as he waits for food to splash up to him, and you may éven hear him 


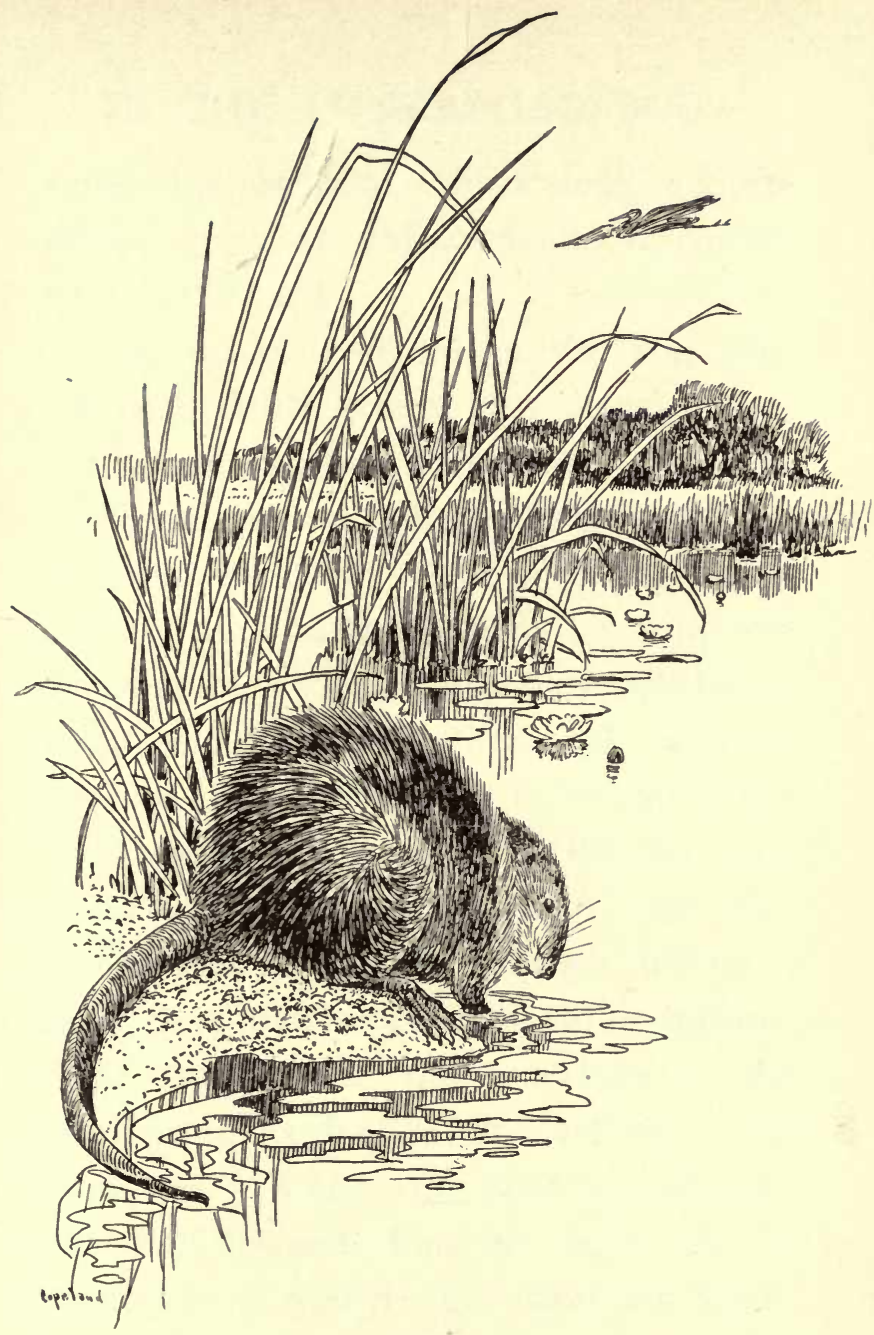

Of a clear midsummer evening you may hear the muskrat grubbing roots there ... and hear his snort and splash when he dives at sudden sight of you 



\section{IN THE PONKAPOAG BOGS}

work his wheezy, dislocated wooden pump, a cry as awkward and disconsolate as the bird.

The muskrats breed in the bog, the bittern had his grassy nest there, and a myriad blackbirds have made the low bushes vocal with their cheery whistles all summer. They are flocking now, getting the young birds in training for the long flight south, but they still hang about the bog and they still whistle merrily. Surely it is not environment that makes temperament. Bittern and blackbird both frequent bogs, yet the bittern is a lonely misanthrope, whom I more than half suspect of being melancholy mad, while the blackbird is as cheery and as fond of his fellows as a candidate. When you hear his whistle you half expect him to light on a thwart, hand you a cigar, and ask after 


\section{WILD PASTURES}

the baby. But the blackbird's election is sure anyway.

Another loved and lovely denizen of these bogs is the wood duck. These breed in the swamp, the mother bird building a grassy nest in a hollow tree, where she lays from eight to fourteen buff-white eggs, and leads her yellow fluffy ducklings to a nearby secluded pool for their first swim. Later they come out into the bog, and ultimately make the pond, where they learn to forage for themselves. By the first of August the mother bird has sent them adrift, in the main, to paddle and flap their way about as best they may. They are "flappers," as the boys call them. That is, they can make good speed along the surface by half running and flapping vigorously, but they cannot yet fly enough to rise into the air. 


\section{IN THE PONKAPOAG BOGS}

One of these young wood ducks came out of the bog the other morning, just at the gray of dawn, and swam over toward the boat landing. He was quite near the shore when I took ship and rowed to seaward of him, thus shutting him off from the open pond and from the bog. Then for an hour or two followed what was to me the most interesting duck hunting I have done for a long time. I could row as fast as he could swim, and I continually edged him along the south shore, getting nearer every minute. I have read much of the marvelous intelligence of wild creatures. Yet I saw little of it in this chase. The duck knew me for an enemy, on general principles, for I was a man, and I was evidently coming after him. Even rudimentary intelligence should have told him to flap for the bog 


\section{WILD PASTURES}

as fast as he could. He did nothing of the sort. He just edged along down the shore, evidently hoping that I was lightminded, and would forget all about him in a minute or two if let alone. But I kept at it until I was so near I could see every one of his already handsome feathers and note the coloring of those parts which had not yet reached the beauty of maturity. I could see the yellow rim of his eye, and still he swam east and swam west but made no real move to escape.

Two things I wished to learn from my wood duck. One was how much general intelligence and real quickness of wit he would show in escaping. The other was how he carried his wings under water if, by any fortunate chance, I should be able to see him swim after he went down to escape me. But at first 


\section{IN THE PONKAPOAG BOGS}

he was so irresolute that he neither dived nor made any vigorous attempt to escape. I got so near, that to avoid driving him up the bank into the woods I had to ease away a bit. Finally, at my second approach, he did try to flap by the end of the boat, but I spurted and headed him off.

It was a long time, and it took much manœuvring to make him dive, but it finally entered his head that he might avoid being cornered and badgered by going under water. This he did, going on a slant just a very little below the surface, probably because he was in too shallow water to go much deeper, and coming up well to seaward. There he preened his feathers, took a sip or two of water and, seemingly, waited to be surrounded a second time.

I rowed out, got on the off-shore side 


\section{WILD PASTURES}

of him, and again began boating him in toward the shore. He showed less uneasiness this time, but dived and swam out again after considerable more pressing. Again and again I repeated this, sometimes getting no sight of him under water, again seeing him move along very plainly. At no time did I notice any motion of the wings under water.

I have been told that wild ducks when swimming beneath the surface make most of their progress with their wings, quite literally flying under water. This may be, but I have no evidence of it in the under-water action of this one.

Again, it has been sagely impressed upon me by old duck hunters that you could tell in what direction from your boat a bird would rise by noting the way in which his bill pointed when he went under. I think it was Adirondack 


\section{IN THE PONKAPOAG BOGS}

Murray in that famous loon-hunting chapter who first made the point, and it has been insisted upon by many another successor. But, bless you, my half-grown wood duck made no difficulty of going down with his head toward the morning and coming up in the sunset portion of the view. He took slants under water and cut semicircles at will. But I could n't see him use his wings while beneath the wave.

Little by little he got over being excited by my presence.: He began to eat bugs off the lily pads as he went by, and now and then tip up for an under-water search. Thus we coquetted with one another all along the southern shore of the pond, and when I finally cornered him for a last time in behind Loon Island he dove without embarrassment and began his feeding as soon as he had 


\section{WILD PASTURES}

again reached the surface. The chase was no longer exciting, and I turned my attention to something else. Then he swam out quite a little further into the pond, preened his feathers carefully, tucked his head under his wing and went to sleep!

Evidently he had decided that I was eccentric, but harmless, and the best way to escape my attentions would be to leave me severely alone.

And there you have it. I think the wood duck is beautiful, but not very bright. Yet it occurs to me that some Sherlock Holmes of the woods may prove, to the satisfaction of Dr. Watson anyway, that he is preternaturally clever, in that this one, though still young, was keen enough to see that from the first I had no evil intentions toward him. 
SOME BUTTERFLY FRIENDS 



\section{SOME BUTTERFLY FRIENDS}

$A_{\mathrm{T}}$ dusk all the edges of the pond are lighted with the white candles of the clethra. Its fragrance has in it that fine essence which goes to the making of the nectar and ambrosia of the gods. He who would sup with them may do so by taking canoe of an early August twilight when the purple arras of the coves glow softly golden with the reflected light of the sunset's afterglow. Then the coarser air seems to have let the light slip from between its clumsy particles, leaving its more ethereal essence still clinging to a more subtle interatomic fluid.

The fragrance of the clethra seems always to me as fine as this spirit of 


\section{WILD PASTURES}

light in the ambrosial twilight of the ripened summer. It is no air-borne delight like the resinous scent of the forest pines or the pasture sweet-fern when the hot sun of midday distills them and the hot wind of midday sends them far to you across the quivering fields. It is something finer, softer, more silkily subtle, which, like the rose gold of the afterglow of the sunset, tints the dusk of the cove between the air atoms, not by way of them.

Then, as the gold glimmers and fades and the pink faints in the cooling purple of the dusk, and the outline of the cove shore slips from the front of your eye to the chambers of memory behind it, so that you else might see it best with the eyes shut, the white candles are lighted and the eager moth sees by them to sup with you and me and the gods on this 


\section{SOME BUTTERFLY FRIENDS}

essence of ambrosia, to tipple on this spirit of nectar which the night reserves for those that love it.

I do not know why the clethra which gleams so white in the dusk should need anything more than its own white beauty to call the moth to its wooing. Perhaps it does not need more. Perhaps all this fine fragrance is but the overflow of its soul's delight at being young and chastely beautiful, and trembling in the ultra violet darkness on that delicious verge of life that waits the wooer. I half fancy that this is true of all perfume of flowers, that it is less a call to butterfly or bee to come to their winning than it is a radiation of delight from their own pure hearts at the dawning of the full joy of living. I am not always willing to take the word of the scientific investigator on these points as 


\section{WILD PASTURES}

final. The scientists of the not very remote past have known so much that is not so!

It is possible that, just as a huntingdog picks up a scent that is strong in his nostrils and has no power in ours, so the flowers that we call scentless send out an odor too faintly fine for our senses, yet one that the antennæ of moth or bee may entangle as it passes and hold for a certain clue. Perhaps the scents that are only faint to us carry far for the butterfly, but if so, and if flower perfumes are made only for the calling of insects, why need they be made so intoxicating to the human senses? The scent of carnations is as pleasing to the soul as a strain of beautiful music, and equally arouses high aspirations and noble longings. So to me the odor of the clethra at nightfall is a 


\section{SOME BUTTERFLY FRIENDS}

tenuous thread of ethereality that reaches far toward a realm of spiritual ideals. It ought to go with a ritual and a vested choir.

I do not find the odor of the pasture milkweed speaking thus to any inner sense. It is just a gentle, lovable, stayat-home smell that surely does not float farther than the pasture bars. Yet of all the plants that have bloomed within my world of garden and pasture this summer it has been by far the most popular among insects. It is not that it is the most attractive to the eye, in any of its forms, for there are many flowers of colors more vivid and to be seen farther, as well as of much stronger scent. Yet all day long you will find it besieged by bees, from the aristocratic Italian worker from the farmer's best hive down to those scallawag bees that 


\section{WILD PASTURES}

make no honey for themselves but lead a vagabond life and lay their eggs in other bees' nests, leaving their young to grow up in unendowed orphan asylums.

Many varieties of ants seek the milkweed blooms, and you shall find about a large clump more sorts of wasps than you would believe existed, yet it is the butterflies who most of all make it their rallying place. Every butterfly in the whole region makes it his business to know each large clump of milkweed, and to make the rounds at least daily.

There, if you watch, you may see the pretty little pearl crescent, whose range is from Labrador to Texas. The shy meadow browns flit out from the shadow of the brook alders and feed for a moment before they take fright at the fact that they are out in society and flit desperately back again. The angle 


\section{SOME BUTTERFLY FRIENDS}

wings flip about like animated questionmarks, and fulvous fritillaries soar sedately, now and then lighting to feed and fold their wings that you may see the big silver spots of the under parts. And so you might name them all, almost every butterfly of early August, all besieging the milkweed so eagerly that you may hardly drive them away.

The fact is they come neither for scent nor sight; they come for good taste - which they find in the honey glands of the peculiarly shaped bloom, which are obvious and sticky and within reach of all. I do not think it is half so much the odor of the flower which draws them, be it never so sweet or so strong, but memory of the honey dew sipped there yesterday or last week. No doubt the love of the milkweed bloom is an inherited tendency, also, 


\section{WILD PASTURES}

bred in the bones from a line of milkweed-frequenting ancestors infinitely long.

Indeed, one of our most splendid butterflies is the Anosia plexippus, otherwise known as the milkweed butterfly, rightly named also the monarch. Every boy who knows the country in summer knows him by his rich, red coloration, his strong, black-bordered wings with their black veins. Every bird knows him too and lets him alone. On the first median nervule of the hind wings of the butterfly is a scent bag whence he dispenses an odor so disagreeable to the bird who would eat him that he goes free, and is not afterward troubled.

Along with the monarch sipping honey with eager industry from the meadow milkweed, you will often see the viceroy, who, as a viceroy should, closely imitates, but does not equal, the 


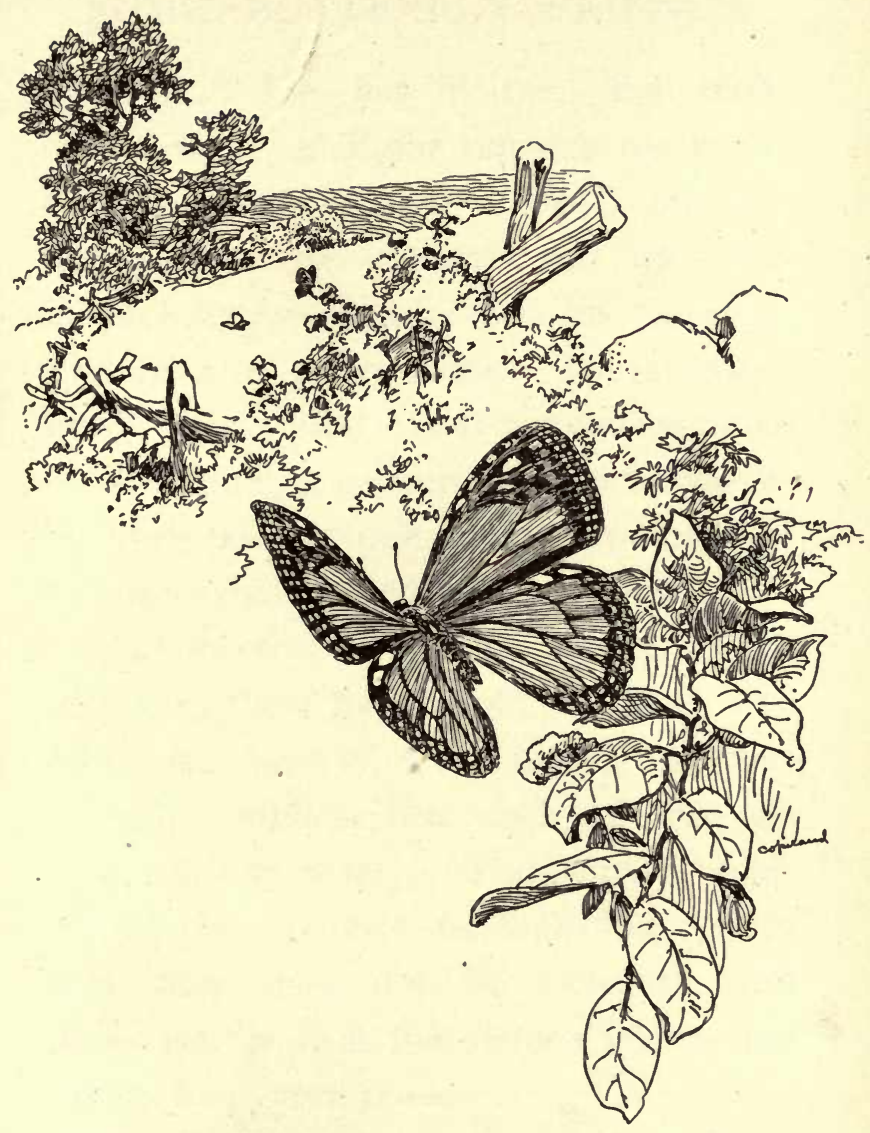

Every boy who knows the country in summer knows him by his rich, red coloration, his strong, black-bordered wings with their black veins 



\section{SOME BUTTERFLY FRIENDS}

monarch. He has neither the monarch's vigor of flight nor his means of defence from predatory birds, but his safety - so the students tell us - lies in looking so much like his superior that he also is let alone. The students go on to say that his is a good example of the imitative power of insects whereby they escape destruction by seeming to the casual eye to be something else.

The viceroy, which is a Basilarchia disippus, thus looks not the least like other members of his family, but consciously mimics the coloring of the monarch for safety. Thus many tropical beetles contrive to look like wasps that they may not be molested, and some insects look like brown leaves and others like green ones.

But do they contrive, imitate, mimic? It is no doubt true that because of the 


\section{WILD PASTURES}

resemblance they escape, but to say that they imitate or contrive or mimic seems to me to be to assume a knowledge of the workings of the inner consciousness of an insect that not even the most careful student can have. I am more inclined to believe that the so-called mimics are fortunate in an accidental resemblance and so escape the destruction of their species which has fallen upon many a less fortunate type.

Yet no butterfly, however exquisite his coloring, or however strong and graceful his flight, twangs with his fluttering wings the fine heartstrings of romance as does the monarch. The first one that came dancing down the sunlight to the sweet rocket in bloom in my garden this spring brought to me a spicy odor of tropic isles. The beating of his wings shed, as he passed, faint 


\section{SOME BUTTERFLY FRIENDS}

fragrance of Mexican jasmine, and I thought I saw slip from them the infinitesimal dust of the pollen of stephanotis lately blooming in the glades of Panama. Three months before he floated serenely beneath my cherry tree he may well have soared through the tropic glades where crumble the ruins of the palaces of the Incas.

His flight, seemingly as frail as that of a red autumn leaf sliding down the October zephyr to carpet the nearby field with rustling fragrance, has matched that of that rifle-ball of bird life, the ruby-throated humming bird. Together they sip the sweets of my sweet rocket in the spring. Together they wing their way south to the region of perpetual summer when the winds of late September promise frost. Sometimes in this annual flight the monarchs 163. 


\section{WILD PASTURES}

pass the sandy stretches of the New Jersey coast in swarms that, stopping at nightfall for rest, refoliate with their folded wings the shrubs left bare by the autumn gales.

It may be that, like the birds, the knowledge of the route they must follow is bred in the marrow of their butterfly bones by the constant use of a million generations. It may be that they simply drift away from the cool wind from the North toward the Southern sun that shines so serenely in the bright autumn days. But whether through the guiding hand of Providence, or inherited wisdom, or a fortunate tact that acting from day to day produces the happy result, this Southern movement in winter is the sole salvation of the species here in the North.

If they did not make these long I64 


\section{SOME BUTTERFLY FRIENDS}

flights we should have no Anosias with us each summer, for unlike other butterflies the frost kills them in whatever form they remain to brave it. All summer long their long, red wings bear them bravely from one clump of milkweed to another. They sip the honey which each floret of the umbels holds forth, the sticky mass the size of a pinhead. They lay their eggs upon its leaves and the black and yellow caterpillars hatch and feed there. Then they hang in a green and gold chrysalis from a nearby twig till the imago, the perfect butterfly, bursts its bonds and sails away to find more milkweed. There may be several broods of a summer, but the frost stops all that. The monarch may not winter here, nor may his eggs or chrysalids survive the cold. 


\section{WILD PASTURES}

Many butterflies, frail though they seem, do pass the New England winter successfully. The Antiopa vanessa, otherwise known as mourning cloak or Camberwell beauty, a handsome brown fellow with blue spots and a pale yellow margin, well known to every one, flits joyously through the woods with the very first warm days of spring. He has been snugged up in some dry crevice, numbed and torpid, but very much alive, all winter. The first genial warmth sets him free, and later I always find his children browsing on the willow twigs over in the cove. They are rough chaps, horrid with bristling black spines and with dull red spots relieving their otherwise plain black hides. But they grow fast, and by and by go out upon a twig and hang themselves, head down, by a little silken rope, swinging there in 


\section{SOME BUTTERFLY FRIENDS}

the wind, simply a dead caterpillar that has imitated Judas.

One day the caterpillar part sloughs off. It is a fairly sudden process. You may paddle by the willows in the morning and see all your little Judases hanging in a row. Paddle back at noon and their skins have shrivelled and slipped off, and you have chrysalids, queer, impish-looking things, swinging there still, head down. You know they are alive; indeed, if you poke them they will wiggle impatiently, but they swing in the wind and give no other sign for a week or ten days. Then they cast a second skin, and pop out full-grown butterflies that stretch their wings for a time leisurely, then suddenly dash into the air and go off over the hill like mad. The whole thing is so sudden! The change, when it does come, is as 


\section{WILD PASTURES}

if some woodland magician had waved a willow wand and said "Abra-ca-dabra; presto, change!" Time and again I have watched to see that caterpillar skin fall off, and again to see the vanessa step forth from the domino in which it has been masquerading, but they have always been too quick for me.

Other butterflies survive in the chrysalis all winter and come forth full grown and fit in the spring. Such may speak to your listening imagination through their beauty, which is often great, or through their resurrection from seeming death, though if you will observe them closely in the chrysalid form you will see that they are not even seemingly dead. Evangelists who have held up the butterfly to us as a prototype of that resurrection which we I68 


\section{SOME BUTTERFLY FRIENDS}

may expect if we are good, evidently never closely observed the chrysalis of a good healthy butterfly, else they had not been so sure of their corpse.

Lately I have had chrysalids of the Papilio asterias, the common eastern swallowtail, in my study. I found the fat black and yellow worms on my parsley and caged them. They soon hitched themselves to the wire netting by their tails, hanging from overhead on a slant, their shoulders (so to speak) being supported by a single loop of silk. If you did but tap on the wire netting or scratch it these chrysalids would wiggle and jerk quite angrily, their action saying plainly, "Can't you let me alone? I'm just having a nap!" No; it is plainly no death and resurrection which makes a butterfly. It is merely a caterpillar who was dressed for the fancy ball all 169 


\section{WILD PASTURES}

the time. He came to the woodland hall in his greatcoat. This he sheds for a domino, in which he masquerades for a time. Then he bursts forth for the final festivities in a robe of princely beauty.

My chrysalids did this only the other day. Wonderful creatures of black and yellow came forth, stretched their wings till I could see the dainty shading of blue and the peacock-feather eye of red and black on the lower part of the secondary wings; then, as I opened the window they dashed madly away as the vanessas do from willow twigs in the cove. The butterfly has been held up to us as an example of lazy dalliance. I have never watched one that was not as busy as a politician on election day. Especially do those just wakened from the chrysalis form rush 


\section{SOME BUTTERFLY FRIENDS}

away as if they knew all their work was before them and they longed to be at it.

Of them all the monarch is not the most beautiful, but I rank him as surely the ablest. His annual migration shows him to have wonderful strength of wing, and either much wisdom or an extraordinarily developed instinct. Very likely he has both. - Further, through accident pure and simple, or else a spirit of adventure fostered by the joys of long annual journey, he is steadily extending his habitat to embrace the known world. Originally of North America only, he has within the last dozen years taken ship for Australia, where he has multiplied greatly in the warmer regions, and has wandered again over sea to Java, Sumatra, and followed the flag into the Philippines. $\mathrm{He}$ is well 


\section{WILD PASTURES}

established at the Cape de Verde Islands, and is doing his best to be happy in the pale sunshine of the south of England, whence specimens are reported yearly. 


\section{THE RESTING TIME OF THE BIRDS}





\section{THE RESTING TIME OF THE BIRDS}

THIS morning I heard the bluebirds again for the first time for weeks. They came up from the pasture to the apple trees and sang their modest little snatches of song in that shyly sweet, reserved yet fond, manner which makes the bluebird the best loved of all our pasture birds. There have been no bluebirds about my garden since the yegg raid of late May and its resulting tragedy. Now they are back, but there is in their call a note of sadness which indeed comes into the voice of every bluebird as autumn approaches, though I think it is accentuated in mine this year. 


\section{WILD PASTURES}

When I say yegg I mean English sparrow, and if I could think of a worse name, equally descriptive of him, I would give it. This is the story of the foul deed, only one of many, no doubt, perpetrated by this cowardly crew. In late March I put out in my garden three bird boxes such as bluebirds love to inhabit. These were immediately inspected by the neighborhood flock of English sparrows, just beginning to pair off, and finally decided upon as undesirable, perhaps because I had intentionally placed no perch before the door.

The English sparrow will build his nest in any impossible place to which he takes a fancy, but he greatly prefers, in choosing a new site, one that has a convenient perch close by the entrance. So these undesirable citizens decided that 


\section{RESTING TIME OF THE BIRDS}

they did not care for my bird boxes and let them alone, much to my delight. Then came the bluebirds, bringing to our cold, raw spring their flashes of blue like bits of a heaven that is fairer than ours, a blue that is hope and dreams of happiness and all things noble yet gentle. There is no color like it as it glints across pale April skies and blooms on trees that have been bare and gray so long. So, too, no bird song is so dear as theirs. It is but a wee, melodious phrase which says again and again, "Cheerily; cheerily." Yet it voices hope and contentment, and is so purely the expression of the joy of gentle, kindly lives that it touches all that is fond and kindly in the listener.

Bluebirds will nest in the hollow of the pasture apple tree or in a last year's flicker's abandoned hole in a decayed 


\section{WILD PASTURES}

stump, but of all places they most love a bird box near a dwelling, and, as I had hoped, a pair came early in April to inspect mine. They looked them all over appreciatively, seeming with delightful courtesy to the builder to find it hard to choose, but finally settled upon one in the pear tree, and began to build.

Meanwhile the yeggs had been watching with jealous eyes, lurking in the shrubbery, sneaking about the eaves and making sallies in small numbers from around the barn. The English sparrow has been called pugnacious. $\mathrm{He}$ is nothing of the kind. $\mathrm{He}$ does not love a fight. Bird to bird, there is nothing too small to whip him. I have seen a chipping sparrow, which is the least among the pasture sparrows, send the poltroon scurrying to shelter with all his feathers standing on end. A cock bluebird, fightI7 8 


\section{RESTING TIME OF THE BIRDS}

ing like a gentleman, and like a gentleman fighting only when he must, will drive a half-dozen of them. The English sparrow has the true instincts of the browbeating coward, and loves to fight only when in overwhelming numbers he may attack a lone pasture bird without danger to himself.

So trouble began with the building, and for a week or so the warfare raged from box to box, the cock bluebird boldly defeating superior numbers again and again, only to have his gentle wife annoyed by other villains while he drove the first away, and his nesting material stolen in spite of him. Finally he resorted to what looked to me like wellplanned and carefully executed strategy, though it may have been merely that fortune which favors the brave and persistent. The pair abandoned the box in 


\section{WILD PASTURES}

the pear tree and started building in the one nailed against the side of the barn. The sparrows followed, of course. Then the bluebirds went back to the pear-tree box. The sparrows followed. The bluebirds then started building in the third box and daily brought material to each of the three, though ostensibly, I thought, to the second and third. At any rate the sparrows seemed to concentrate their attention more on these boxes. Meanwhile the bluebirds quietly completed the nest in the pear tree and later laid their eggs there, in comparative peace.

The sparrows did not build in either of the other boxes. They did not want to. Neither did they care particularly about the material which they stole, for they did not continue to take it after the bluebirds had finished the pear-tree nest and were in a position to defend I8o 


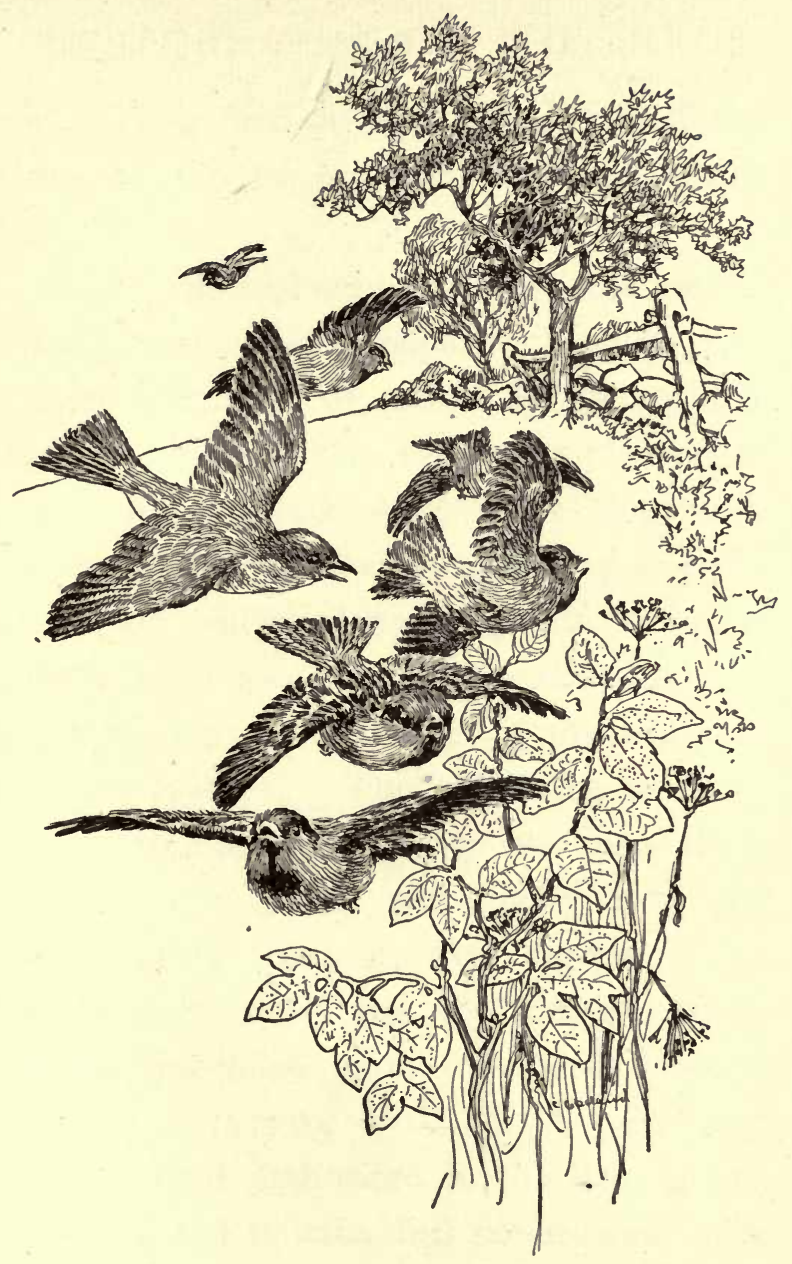

The English sparrow has the true instincts of the browbeating coward 



\section{RESTING TIME OF THE BIRDS}

it. Their action was simply hoodlumism of the lowest and most despicable kind.

This was bad enough, yet it was merely petty annoyance compared to the deed without a name of which they were later to be guilty. The two young birds in the bluebird box were more than half grown. The blue was beginning to show in their wings along with the white of the conspicuous, growing quills, and the fuscous margin was already touching the breast feathers. The old birds, working with tremendous energy to feed these hearty youngsters, were both busy and often away from the nest together.

At one such time the English sparrows descended upon this nest, entered, drove the young birds out to die upon the ground, unnoticed in the long grass, and started to take full possession. The 


\section{WILD PASTURES}

bluebirds, returning too late, drove them away with more than usual despatch. This first called the affair to my attention. But I was too late.

The young birds were dead and the sparrows were chattering in raucous jubilation over it, now and then giving a squeak of fright or pain as the male bluebird singled out an individual and attacked him with a fury of which I had not believed him capable. Soon, however, he ceased, and the two twittered mournfully about the tree for hours, again and again poising in fluttering flight before the door of their despoiled home and looking eagerly in, as if they could not believe that the young were indeed gone. Later they went silently away. No doubt they found another home in some hollow tree of the remote pasture and raised another brood. 


\section{RESTING TIME OF THE BIRDS}

But my boxes have stood tenantless ever since.

The worst of it is there is little I could do either in the way of prevention or revenge. I did get out my big old ten-bore duck gun, which I have not had the heart to use on a bird, even a coot, for a dozen years, and began cannonading the miscreants, but this was more disturbing to the neighbors than to the sparrows.

One of the gentlest nature lovers I ever knew, wise in bird ways and very fond of all birds, used to say that he wished all the English sparrows in the world had but one neck, and that he might have that neck in his hands. I wish he might, too.

So, after weeks of absence, the bluebirds have come back. Their specklebreasted young, which they would have 
brought up among my apple trees and in the cloistered seclusion of the lilac bushes, have grown up in the pasture instead, and very likely their plans for next year will include the pasture wildapple tree rather than my bird box, and they are far shyer and less responsive to my advances than they would have been. Their song has in it a plaint of autumnal regret. In the spring they sang, "Cheerily; cheerily." Now they say, "Going away; going away." It has in it something of the quality of "Lochaber no more."

But it is not merely the bluebirds which have been silent for some weeks and are now beginning to sing again. The time between early July and midAugust is a period of retirement for all birddom. The mating season, with its soul-stirring ecstasies, the labor of nest I 84 


\section{RESTING TIME OF THE BIRDS}

building, the anxieties of brooding, have been followed by the tremendous exertion of caring for that nestful of young birds. A healthy fledgling will eat almost his own weight of food in a day, and by the time he is able to fly and chase the old birds around for more the father and mother are worn to a frazzle. I really believe the youngsters are weaned only when their demand for food becomes so enormous with their completed growth that the parents cease to supply it through sheer physical exhaustion.

I once reared a pair of young crows by hand, taking them from the home nest in a big pine, leaving three others quite enough I afterward thought - for the parent birds. They were negroid, naked, pod-bodied creatures at the time, with long clutchy claws, ridiculous stubs of wings, and, ye gods, what mouths! I 85 


\section{WILD PASTURES}

When I fed them I used to clutch something with one hand lest I fall in. And I was incessantly feeding them. Anxious to treat them kindly and finding that frogs were a most acceptable diet to them I depopulated the township of Rana virescens and allied species. Then I found that fish would do about as well, and I fished until there began to be a shortage of angle-worms in the community. Yet still the creatures grew apace and demanded more food.

By and by they got big enough to use their wings and, recognizing me as their undoubted parent, came flapping and clawing after me wherever I went, yelling, "Caw, caw, ca-aw-aw," in most heartrending crescendo. Then did I realize to the full the responsibility of being a father bird. Stuff those clamorous creatures as I might, they still pleaded I 86 


\section{RESTING TIME OF -THE BIRDS}

in agonizing tones for more, and no one not cognizant of the facts would have believed that they were ever fed. The lamb that loved Mary so, and followed her also, was not a circumstance to the clamorous devotion of those two young crows toward me, their foster parent.

My one fear for weeks was that the resident agent for the S. P. C. A., who was a vigilant and tender-hearted lady of undoubted indiscretion, would hear their evidently unanswered appeals and proceed against me. : She could have convicted me on the evidence in any district court in Norfolk County; and yet those young birds were eating everything there was in the place outside of cold storage.

Such is the appetite of the growing bird. Yet there comes a time in the passing of the summer when the young- 


\section{WILD PASTURES}

sters are taught, or learn through necessity, to forage for themselves and cease their fritinancy. Then the thickets are strangely silent. The youngsters no longer yearn noisily and they have not yet learned to sing. The old birds have ceased singing. Indeed, there is nothing left of them but their bones and feathers, and that atmosphere of conscious rectitude which comes with successful completion of a noble and herculean task. And then even their feathers begin to go, for the moulting season is at hand.

No longer does the male scarlet tanager sit like a lambent flame in the top of a tree and warble, "Look-up, way-up, look-at-me, tree-top." His scarlet suit begins to fade, grow dingy, show signs of wear, and finally go all to pieces while he sits mute and dumpy in the shadow. By and by the scarlet will have changed I 88 


\section{RESTING TIME OF THE BIRDS}

completely to a dull olive-green, like that of his inconspicuous mate, and though he still retains the black of his wings and tail you would not know him.

So the bobolink who swung so conspicuously on the meadow grass in June in his black and white suit comes through the moulting season brown as a sparrow. The vivid blue of the indigo bunting falls from him in patches and is replaced by grayish brown in a large measure.

No wonder that, utterly tired out and their brilliant plumage scattered and changed to dull and rusty colors, the birds are silent for a time, waiting for strength to recuperate. Some of them seem to retain enough courage and vitality to sing mornings through the moulting season, notably the robins. I suspect, though, that these faithful few - for the robin singers of the morning of the first 


\section{WILD PASTURES}

day of August will be as one to twenty to those of the first day of June - are gay young sports who did not care to marry, or who, disappointed in love, still sing to keep their courage up. It is the best singers who are most strangely silent now, as they have been for weeks; nor will most of them be heard until next spring, hereabouts.

My catbird was so sorrowfully unseen and unheard that I began to think the cat had got him, till I hunted him up, down the hill among the scrub oaks. $\mathrm{He}$ was as dilapidated and passé-looking as his nest in the lilacs; as if, like it, the young birds had kicked him pretty nearly to pieces before they got through with him. But he perked up a bit when he saw me, flipped an apology for a tail, and miaued in a manner that was humorously unlike him, it was so deprecatory. 


\section{RESTING TIME OF THE BIRDS}

But that was a week or ten days ago. Yesterday I heard some bird cooing a little song to himself out in the arborvitæ trees at the foot of the garden, and slipping quietly up found that it was the catbird again. He was quite sleek in his new coat, and he was practising his song in a delightful undertone, as if to be sure that he should not forget it altogether.

In four or five weeks more he will begin to flip saucily across the miles of country that separate him from his winter home in Southern Florida, or perhaps farther yet in some stretch of primeval forest that I myself have seen and loved in the heart of Santo Domingo. He will not sing his song there, high on some giant ceiba or swinging on the plume of some royal palm. He may not sing it again here on the tip of the tallest white lilac bush. but I know that, there 


\section{WILD PASTURES}

or here, he will practise it now and then in that soft, sweet undertone which you would not believe of a catbird, and be ready to send it forth in jubilant peals when his strong wings bring him back again next May. My bluebirds may winter with him; and if they do I have hopes that he may persuade them to try my pear-tree box once more next spring. 


\section{THE POND AT LOW TIDE}





\section{THE POND AT LOW TIDE}

A LL about the pond the woodland folk are enjoying shore dinners, for it is the time of ebb tide, and a wonderfully low ebb at that. Not for a score of years do I recall such low water. Where, on the ebb of ordinary years, the crow has been able to find one freshwater clam, he may now feed till he can hold no more, for the drought has been long and severe, and the pond has been drained to the very dregs.

I say fresh-water clams, for that is the name commonly applied to the creatures, though I know that I might more properly call them river mussels, and if I wished to be severely scientific I should say Unio margaritifera, though it is diffi- 


\section{WILD PASTURES}

cult to be sure of your margaritifera, as there are about fifteen hundred species of unios known to people who classify creatures, and most of these are found in the rivers of this country.

Little do the crows care for that. In the sunny coves they have their clambakes, and as I slip slyly up I fancy I hear them smack their mandibles. As I round the screen of shore-loving button bushes, I know I shall come upon them, and $I$ expect to find them seated in riotous fellowship, with napkins spread across broad waistcoats, dipping delicious mouthfuls in melted butter and tucking them away behind the white napkins. I have always missed the napkins and the butter dishes, but the shells are proof enough of what has been going on. If the mother crow carries the table furnishings away with her when she flies, 


\section{THE POND AT LOW TIDE}

that is no more than human picnickers do when driven from the sea beach.

The pond when full is ten feet deeper than it is now. In May the water lapped the forest roots on its edges; now from the forest to the mud of the very bottom where still the water lingers a strip of slanting beach stretches for a hundred yards. The crows are not the only creatures which have made tracks on this. Close by the edge in the soft mud the heron has walked with dignity, leaving footmarks that proceed precisely. The heron may not have large ambitions, but he is purposeful and does not turn aside. The crows gurgled and ha-haed over their clambake; the heron takes his fish course as solemnly as if he were taking the pledge.

All along you will see where the squirrels have come down to drink, skipping 


\section{WILD PASTURES}

vivaciously, taking a sip here, bouncing away to examine something there, remembering that they came for a drink after all and taking a good one, then hurrying back with long leaps in a straight line for the trees. The squirrel is not solemn, far from it, but he is business-like, and though there is humorous good fellowship in his every hop, he nevertheless does not linger long from his work.

Very different from this is the track of mister skunk. He wanders aimlessly along, often as much sidewise as straight ahead. The skunk does n't know where he is going and he is n't even on his way. I never see his tracks, whether on the pond shore or elsewhere, but I renew my doubts as to his habits. $\mathrm{He}$ is out much too late at night. His tracks show it. I think he had his drink before 


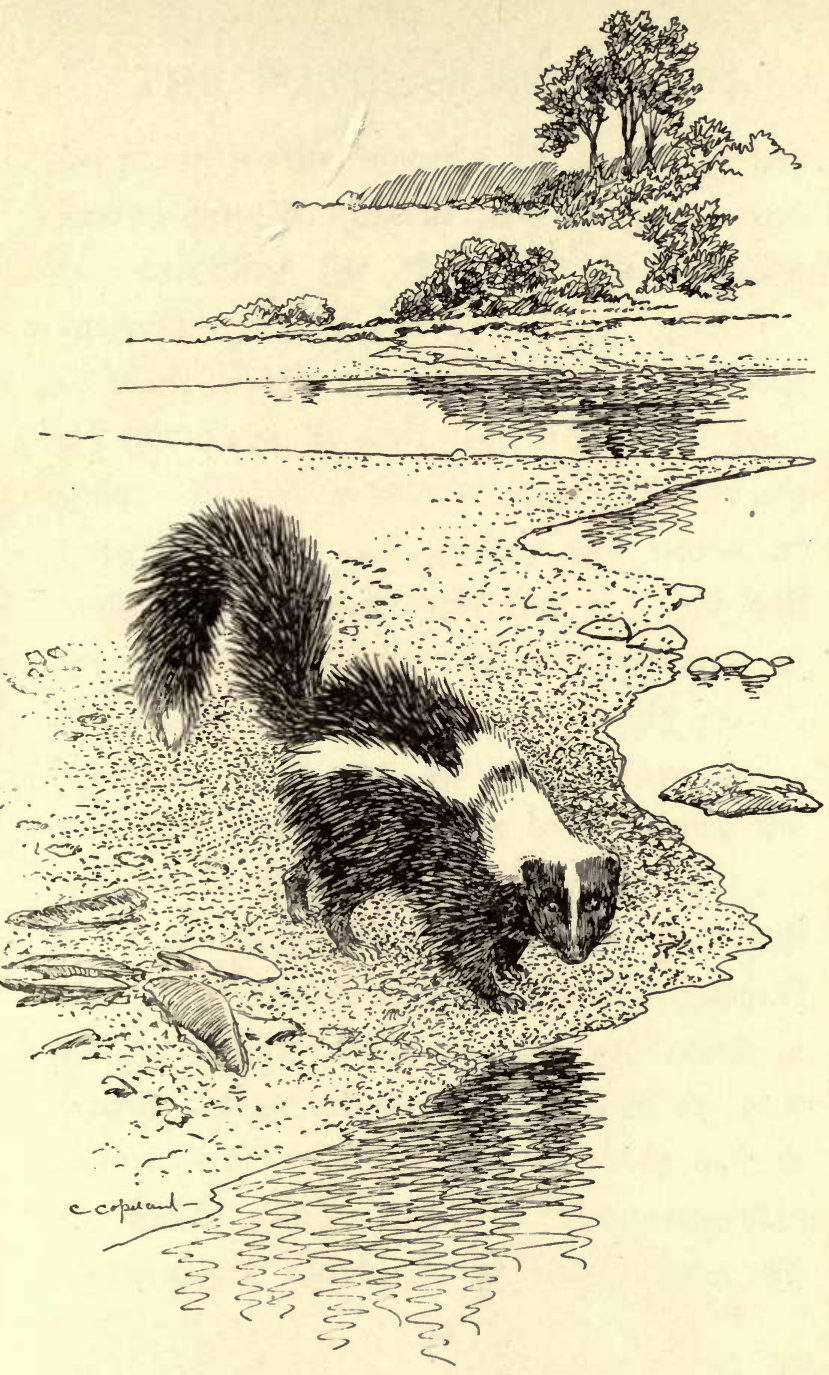

The skunk does n't know where he is going and he is n't even on his way 



\section{THE POND AT LOW TIDE}

he came to the water. Probably he too knows how toothsome are the unios and is searching for them in his maudlin fashion.

Then there are the muskrats. They do not have to wait for their clam banquets till the water is low. They are expert divers and gather the unios at such times as suit their fancy. You will see their tracks in regular runways in the shallow water of the muddy coves, whence they are apt to follow some trickling streamlet to the bank where the summer burrows are at high water.

Later, along the marshy edges you will find their winter teepees, piled to conical heights with sods and roots, with a warm refuge above the ice and an exit below, whence they may swim in search of food. The tracks of the muskrats show every mark of the industrious vil- 


\section{WILD PASTURES}

lager. They stick close to well-traveled paths, and though the muskrats are out nights no one would for a moment question their temperance and industry. Their characters are excellent ones, beyond suspicion, and their tracks show it.

On the pond shore at ebb tide the glaciers, too, have left their tracks, though it is probably several hundred thousand years since any have been this way. Where there are granite ledges you may know that these were here before even the glaciers stalked solemnly by, for they show where the ice in grumbling grandeur ground small stones against them and gradually wore out ruts in the enduring granite by force of attrition.

The track of the glacier is like the trail of the serpent, - it leaves no toemarks, but its sliding progress is unmistakable. Side by side with the ledge 200 


\section{THE POND AT LOW TIDE}

which shows these striæ you may see on the soft mud imprints of this year's leaves, dropped a moment there by the wind, then whirled away again, but leaving their tracks behind them. This mark of the season may be obliterated by a breath, or it may be covered with sifting silt and finally harden into sandstone and bear the trail of the leaf as far down the ages as has come that of the glacier. Here are moments and æons elbowing one another for place.

Other interesting records of past time may be read in Stumpy Cove, which is still the wildest and most secluded of spots, though the trolley tripper has found the pond and builds his bungalows on its shore, sinks his tin cans in its waters, and scares the bullfrogs with his phonograph. The tin cans will not last long, however. Fresh water in motion is con- 


\section{WILD PASTURES}

tinually giving up oxygen, and this with the humic acid of the mud bottom will soon scatter these disfigurations in scales of brown oxide. But all these solvent forces, acting through two centuries, have had little effect on the stumps of Stumpy Cove.

The heart-wood is still sound, their interlaced roots tell the story of what happened on the spot in the rich muck of the swamp, as Stumpy Cove was then, before Myles Standish had set foot on Plymouth Rock or the first white man had spied inland from the summit of Blue Hill. For the pond as it is now is only about a hundred years old. For a hundred years before that it was a meadow, flowed occasionally by the farmers of the region about it.

Before that Stumpy Cove was a great white-cedar swamp and the great white 


\section{THE POND AT LOW TIDE}

cedars stood in it, two feet in diameter, their clean straight trunks running up fifty feet or more without a knob or limb. This natural meadow with hay for their cattle for the cutting, these cedar swamps with their century-old growth, were what attracted the first settlers to this region, and hardly had the dawn of the sixteenth century come over the Blue Hills before their axes were at work in Stumpy Cove and similar swamps all about, getting out shingle stuff for the Boston market. But whereas in all the other swamps the young cedars were allowed to grow in again for succeeding generations of woodsmen, here new conditions arose.

The meadow was flowed intermittently for a century; then the pond grew out of it. Not only might no seedlings find roothold there, but the very black muck 


\section{WILD PASTURES}

in which they might grow was washed away from the roots of the great stumps. These, in the main, have endured, losing their bark and sap-wood, but with the heart-wood still firm after the lapse of two centuries.

Here at this ebb tide I read the record of growth of trees that had their beginnings more than three centuries ago. These roots so twine and intertwine that the original sap, drawn from the tender tips, must have nourished any one of several trees indifferently, for heart-wood joins heart-wood in scores of places near the stump and far from it, showing that each tree stood not only on its own roots, but on those of its neighbors all about it; not only was it nourished by its own rootlets, but by those of trees near by. No gale could uproot these swamp cedars. United they 


\section{THE POND AT LOW TIDE}

stood and divided they might not fall. It is a curious method of growth, and I dare say it obtains in many swamps where the white cedars stand close, but under no other circumstances could it have been revealed to me, casually strolling that way three centuries after it happened.

At high water all these curious roots are submerged and you see only the butts of the trees, numerous miniature islands on which many an alien growth has made port. Herê in June the dour and. melancholy cassandra disputes the footing of the wild rose, and the huckleberry and sweet-fern twine in loving companionship, afloat as ashore. Here intertwine the sheep laurel and the hardhack, the meadow-sweet and the marsh St. John's-wort, garlanding the white skeletons of the ancient trees and mak205 


\section{WILD PASTURES}

ing them young again with the odorous promises of spring.

- In midsummer, among patches of green and gray moss, you will find tiny, diamond-like globules glistening. These are the clear, dew-like drops of glutinous liquid which gem the leaves of the Drosera, northern representative of the Venus's fly-trap. This, the Dionaea, catches flies by means of a steel-trap leaf which closes on them when they light on it. This other, the Drosera, is not so active. It attracts insects with its honey dew, holds them with sticky glands, and grips them, little by little, with bristles. It is a curious and beautiful little plant, and one would hardly think it carnivorous to see it adding its diamond ornaments to the floral decorations which beautify the ancient stumps all summer long. 


\section{THE POND AT LOW TIDE}

Yet of all the life histories revealed by the pond at low tide I still think that of the Unionda the most interesting. You find them all along above and below the margin of the shallow water, their shells most wonderfully streaked with olive-green and pale-yellow in alternate bands, till one might think he had found nodules of malachite which the long-ago glacier had culled from some Labrador ledge and ground to unsymmetrical ovoids before it dropped them on the old-time meadow marge. In certain individuals and certain lights the shells of these obscure creatures send out gleams of green and gold, like gems that have soft fires within them. It is as if an opalescent soul dwelt within, and the thin shell which a crow with his bill may puncture with a blow was so constructed as to hold in the reds and blues of the opa- 


\section{WILD PASTURES}

lescence, but transmit the greens and gold.

You find many with only the backs of their shells sticking out of the mud. This may be the creature's natural position, but I find far more of them lying quietly on their sides in the shallow water, rocking gently to and fro in the placid undulations as if they were there but to show me their shining colors. But if you watch one intently for a time you will see him open his shell cautiously and put out one foot. This is his best, for it is all he has and he puts it foremost. It is very white and clean, and it might as well be called his tongue, for with it he licks his food. It is half as long as he is, and when he has put it out as far as he can, or as far as he dares, a fine white fringe grows on its outer margin. Thus he gathers in mi208 


\section{THE POND AT LOW TIDE}

nute animalculæ or refuse matter from the surface of the mud, for his stomach's sake.

It is a rather interesting thing to stand by and watch a Unio margaritifera daintily putting away his own particular brand of little necks and mock turtle. At the least untoward sign of interest in the affair, however, he shuts up like a clam, and you will need your pocket-knife if you wish to see more of him.

Where the water is only an inch deep or so over the soft ooze of the bottom you will see where the unio has used this so-called foot as a foot should be used, for he not only stands on it, but walks with its help. These signs are curiously erratic marks drawn as with a sharpened stick for a distance sometimes of yards. If you will inspect the sea209 


\section{WILD PASTURES}

ward end of this trail you will find a unio in it, generally a young one, for it is he that has left the mark behind him in his travels. For the unio at a certain age is a great traveller; that is, when he is very young. The adults foot it, but the young before they reach their full growth ride, some of them by what you might call the lightning expresses of the pond world.

If you will split a big one at this time of year you will be likely to find within an astonishing number of eggs. These are carried in brood pouches that seem to occupy pretty nearly all the space between the shells. In seeing them you wonder vaguely where there was room for the bearer of this amazing progeny. Just where they are these young unios grow to maturity of a certain sort, forming minute shells which have hooks, 


\section{THE POND AT LOW TIDE}

forming also peculiar organs of sense.

The hooks and the sense organs are provided that they may not miss that free ride which is the privilege of every young unio if he is to reach the period of adolescence.

At the moment of being sent forth from the home shell the golchidium, for that is what the scientific men call the unio at this stage of the affair, begins to hunt, aided by his sense organs, for a thoroughfare. Here he takes the first conveyance, whether the slow coach of the sluggish hornpout, the bream automobile, or the pickerel flying-machine. To the first fish that comes by he attaches himself, oftentimes to the gills, and there he rides and, like most travelers, continues to develop.

By and by, being " finished" by travel, he gets off his vehicle at some convenient 


\section{WILD PASTURES}

station, drops into the mud, and is ready to lecture, or so I fancy it, before any of the unio women's clubs on the world as he has seen it. Not until then does the unio, and then only if he is a margaritifera, begin to accumulate pearls.

By what mystery of sunlight and shallow water the unio has acquired the lucent green and gold of the epidermis of his outer shell I do not know, any more than I know what pigments paint or what naiad fingers hold the brush that paints the gold in the heart or the pinky green in the outer sepals of the waterlily. The two find their sustenance in the same mud.

But even if I could tell this I might well pause in wonder over the beauty of the inner shell of this pulseless creature of the ooze. Perhaps the golchidium, darting back and forth beneath the rip- 


\section{THE POND AT LOW TIDE}

ples of the surface during its days of travel, catches the radiant blue of the sky, the rosy flush of dawn, and the glory of the rainbow all shivered together in exultant light to make the nacre of the inner surface of its growing shell. For nowhere else in nature may we find such softness of coloring holding such gleams of azure and of fire. The opal beside it is garish and crude. Mother-of-pearl we call it, for out of the same source is born the gem which may be worth the price of a king's ransom.

The unio is the good girl of the fairy tale, for from its lips fall pearls that confound the divers of the Orient. Not from Ceylon nor Sulu nor the Straits of Sunda nor the Gulf of California have come such pearls of bewildering color and fascinating shapes as have been taken from the river mussels of our 


\section{WILD PASTURES}

American streams. For all I know the shallows of my pond may hold a necklace of such value that its fellow has never yet circled the throat of a queen. If so I hope no one will ever find it out, for an ebb tide such as this comes only once in a score or so of years, and when the next one is here I want still to find the beach beautiful with the green and gold and mother-of-pearl of the unios. 
HOW THE RAIN CAME 



\section{HOW THE RAIN CAME}

THE Spiranthes gracilis is commonly called ladies' tresses, which is a very polite name for it, for nothing can be more beautiful than the tresses of ladies. It is like its name in that it is beautiful, but not otherwise, for it is a flower not of tresses, but of fine eyelashes of pearl set in a spiral on jade. The rain this morning dropped transparent, colorless pearl tears on the tips of these eyelashes, and as they twinkled toward shy smiles the tears ran down the spiral to be eagerly kissed away by the small grasses that always cling about the feet of the spiranthes in mute adoration.

Near by slender varieties of gerardia held up rosy cups to drink these clear 


\section{WILD PASTURES}

pearls, finding in them a medicine that shall cure all ills. In the rain the fountain of youth wells up in the cup of every flower that waits in the soft pasture grasses and the grasses themselves drink eagerly. The cedars deck themselves in these clear pearls, wearing garments fringed with them and ropes and necklaces without number, and letting their prim propriety be so softened that they are no longer firm and erect but take on curves of soft roundness that should go with pearl-embroidered garments.

Yesterday there was in all the pasture people a certain puritanical sternness of demeanor, a set holding fast to the narrowing good of life, a tightening of the muscles that are weary with a long strain but may not for the good of the soul loose their firm grip, for yesterday 


\section{HOW THE RAIN CAME}

the pasture was dry and hard with the leanness of the long summer drought.

To-day has come the first of the fall rains and these puritans are stern and set no longer, but relax into swaying curves of lissome beauty that entrance you. It is as if, after coming as you thought to a Sunday service of the old Calvinists, you found it transformed into a grange picnic of wood nymphs.

The pines indeed, which always stretch out their arms in Sabbath-like benediction, seem asking a pious blessing on all these, their pasture children; and they fold their slim leaves together like hands in a soft prayer of thankfulness. But the soft rain cuddles them as well, and before they know it they are decked with the clear pearls as for a bridal and their plumes nod in reverence, yet are so beautiful in gems and there is such a 


\section{WILD PASTURES}

soft grace in their curves - they that stood so grim and sombre before - that each tree seems like some bounteous and beautiful woman, arrayed for wedding festivities, who yet bows a moment at a sanctuary in prayer, even as she joins the guests.

The rain had been long coming. A solitary quail predicted it; the first I have heard since the severe cold and deep snows of three winters in succession not long ago. I had thought every quail smothered in the white depths or frozen by the bitter cold. Three years is a long time not to hear a quail whistle, and this I believe to be no survivor of the old stock, but one that has worked up from Southern fields where the snows were less deadly during those rigid winters.

It is pretty hard to tell whether a 220 


\section{HOW THE RAIN CAME}

quail is simply announcing his own name for all who care to hear, or making a weather prediction. Jotham, one of the farmer's men who knows all, says it is simple enough. In an announcement he says, “ Bob, Bob White." The weather prediction is different. Then he says, "Wet, more wet." All you have to do is listen.

This is like Jotham's grandmother's recipe for making soap. You collected potash from the hearth, added water in an iron kettle, and bćiled till a certain thickness was reached. You would know this point by placing an egg on the surface, and if the concoction was right the egg would either sink or swim, the old lady was blessed if she could remember which. This is a way that successful oracles have. That one at Delphos did it. 


\section{WILD PASTURES}

So, when my lone quail sat on a rock in the pasture, tipped his head back a little, swelled his white throat and whistled, round and clear, I went out to meet him, scanning the sky meanwhile for a change of weather. The sky of the day before had been like a brass bowl shut down over the gasping land. Shrubs of the upland hung their leaves piteously, the tougher herbs wilted, and the tenderer ones dried up and died.

On such days when the long summer drought has wreaked its worst, when the parched pasture lies on its back, openmouthed, gasping for water, when even the pond which has given so freely for the refreshment of the pasture people has shrunk back upon itself till a rodwide rim of gravel and rough stones forbids them to come down and drink, I love to go down to the water's edge and 


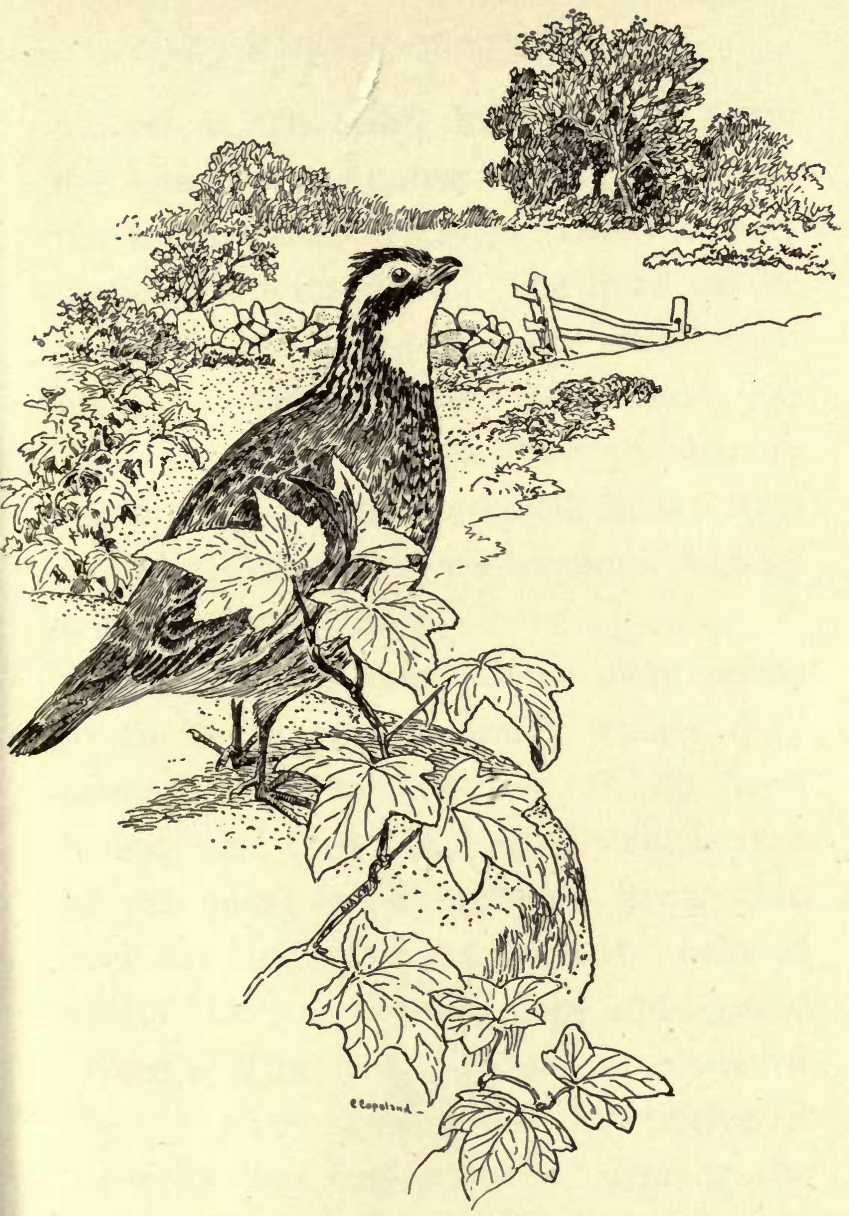

My lone quail sat on a rock in the pasture, tipped his head back a little, swelled his white throat, and whistled 



\section{HOW THE RAIN CAME}

marvel at the hedge hyssop. All along the shore the summer drought forbids the water-weeds to grow. This rod-wide space is not for them. The flood of the winter and spring denies other land plants a roothold; yet, just when you think the shore is to be bare and barren for always, troops forth the hedge hyssop and clothes it with verdure, lighted with a golden smile.

The common name of the plant seems to me to express ingenuity rather than purpose. It has nothing to do with hedges and is not a hyssop, which is a garden plant belonging with thyme and lavender and other sweet herbs beloved of old ladies in kerchief caps and figured gowns. The hedge hyssop is none of these. Nine months of the twelve it bides its time under water. During the other three it glows in golden content- 


\section{WILD PASTURES}

ment on the sandy stretches left bare by this yearly receding tide, climbing along the rocky shore and filling every crevice, lifting its yellow cups to the glare of the brazen sky and distilling subtle perfume to the antennæ of the little low-flying insects that are its friends. Yet if its common name means little, that given it by the botanists fits. Gratiola aurea may well mean a plant that is golden grace or a golden benediction, as you choose to take the Latin.

The day before, then, I had no heart for the upland pasture, but Jotham's reading of the quail had been the right one, for yesterday the brazen look was all blown out of the sky by the south wind. It did not leave it clear blue, for that would have meant cooler and still dry, but put into it a pallor that seemed to well up from all the horizon round. 


\section{HOW THE RAIN CAME}

It was not the pallor of clouds, for there was not even a cumulus thunder head in sight, but the pallor that comes with the wind that has a storm behind it, yet is to blow itself out before the storm arrives.

The cuckoo, flitting jerkily from one thicket to the next, noted this pallor from the corner of his eye and thenceforth through the day croaked to himself as he went his caterpillar-hunting rounds. "Clackity clack; tut, tut; cow, cow, cow," he clucked musically, which is his way of saying, "Oh dear, it is going to rain and the caterpillars will be all soggy." Jotham says the early settlers out here in the Dorchester backwoods taught the cuckoo to work for them, but that he was so lazy that their descendants, getting better help, gave it up, and that the cuckoo soon forgot all 


\section{WILD PASTURES}

he knew about farm work except calling the cows.

Every bluejay is a born tease, and in the late August drought goes about crying " Rain, rain," because he knows there will be no rain. He does it merely to fool the pasture people and then chuckle in his phonograph twang over their misery when no rain comes.

Yesterday when he smelt the south wind and saw that sky pallor he stopped calling "Rain, rain," for he knew it was coming. Instead he fluttered round and round the pasture, ducking in among the boughs of the pines and ejaculating, as if he were surprised to find it so, "Clear, clear." I fancy all the wild creatures of wood and pasture know the signs better than I do and could announce the rain if they would long before I know that it is coming. All the outdoor world 


\section{HOW THE RAIN CAME}

was sure of it yesterday. With the very first show of that paleness in the skyor was it something in the touch of the wind? - the drooping plants lifted their leaves to be ready for it. I could smell it in the falling of the wind at sunset; they seemed to smell it in mid-forenoon while yet the wind was rising.

On such days looking across the pond toward wind and sun there is a peculiar blink in the light reflected from the surface of the waves which you do not see if fair weather is ahead of you. The pale sky seems to reflect blackly in the water. Down to leeward the shore poplars stand silvery white, a quivering, flashing silver under the lash of the wind. The swamp maples lose their green and turn pale and the willows lighten up in color.

It is the turning of the leaves in the 


\section{WILD PASTURES}

wind. You may say that they would turn in any wind and show their lighter under sides, and this is true, yet there is a difference in the appearance when it is a rain-bringing wind. I cannot tell you why this should be, but the difference is there. It may be that a moist wind relaxes the tension of the petioles more than a dry one and thus lets the leaf lie flatter, giving a little different look to the tree as a whole. The weather-wise older people grew up on the land instead of within walls and they were wont to say, "The leaves are turning in the wind and it is going to rain." Like the pasture people they knew.

By nightfall the weather bureau suspected something but was not quite sure what. They hung out the "possible rain" flag, and all the crows in the pine228 


\section{HOW THE RAIN CAME}

wood, congregating now in bigger and bigger flocks, practising, I take it, for their labor-day parade, went into fits of laughter. "Haw, haw, haw!" they shouted, and whirled up into the sky and took a look about and dashed down again, convulsed. "Haw, haw, haw! Possible rain; here's the sky just ready to spill out a twenty-four hour soaker!"

The wind went down with the -sun, and the willow and maple leaves were green again for a little before they faded into the growing purple of the dusk, but with every faint sigh of the failing breeze the poplars loomed white again with a radiant ghostliness which seemed to people the rustling dusk with softly phosphorescent spooks. You will see these other-world visitors to the pond shore only on such a night when the wind is right. 


\section{WILD PASTURES}

There was no glow of rich color in the sky at sunset. Instead the dusk hung violet gray draperies all about the horizon, - curtains that veiled but did not hide the evening stars, shutting them almost out near the horizon and leaving them comparatively clear at the zenith. In such dusk stars do not twinkle, they blink, and that is a sign of rain which all the pasture people that have eyes know well.

Those that have ears and no eyes may know what sort of a night it is as well, for there is some quality in such an atmosphere which makes sounds carry far. The rap of a paddle on a canoe seat a mile away up the pond sounds right in your ear. A train roaring through the wood three miles distant seems so near that you involuntarily look around lest it be coming behind and run over you. 


\section{HOW THE RAIN CAME}

On such nights speak low if you do not wish the whole world to hear, for the air all about you is a wireless telephone receiver tuned to your pitch. Those gray rain curtains which the dusk has hung all about the horizon have made the whole world a whispering gallery.

Sometime in the night the wind dies. It passes away so peacefully that no mirror held to its lips would note that last sigh. But the stars have known it all the evening, and that is why their eyes blinked so. It was to keep back the tears. Then the stars vanish and the night is dark indeed.

Scents carry far on such a night, not only those of the pasture world, which are pleasant, but those of the more distant town, which sometimes are not. The air is not only telephonic but telefumic. The distant leather factory sends 


\section{WILD PASTURES}

out a faint but characteristic odor by which you might hunt it across country for a lustrum of miles. The sooty emanation from my neighbors' chimneys is pungent in my nostrils, though their houses are a mile away. I think I can tell which is which, for the fireplace smell differs from that of the furnace, as does that of the parlor stove from the range. Agreeably these are forgotten, for something has crushed sassafras leaves over on the pasture knoll and the fine fragrance comes to drive away thoughts of the others.

As the night was gray, which foretells rain, so the morning breaks crimson, which announces it. No bird heralds this dawn, no chirping insect sends its voice questing through its shades. The sky hardly lightens up; it is rather that the darkness turns red. Nor does the 


\section{HOW THE RAIN CAME}

light come from the sky when it does come. It wells up from the earth instead, for when the crimson is gone the sky is still black with shadows, while the pasture grows distinct in a gray outline wherein is no color.

A stillness of expectation broods all things, - a stillness so intense that the first rain-drop sounds like a pistol-shot as it strikes a leaf near you. Then there is a volley and further silence for a brief space, followed by a crepitation all about you. Those first heavy drops have been followed by lighter ones, and this crepitation merges into a steady drumming; which becomes a low roar to your ears made sensitive by silence and faint sounds. The first of the fall rains has come, and the summer suffering of the pasture people is at an end. 

INDEX 



\section{INDEX}

A

Adder, flat-head, I28, I29

Admiral, white, 7 I, $72,75,78$, $8 \mathrm{r}$

Alder, 5, 15, 40, 52, 82, 94, I 8 , I I I, I I 2, I I8, I 40, I $4 \mathrm{I},{ }_{5} 8$

black, 139

white, 35

Alice-in-Wonderland, 88

Ambergris, 40

Angle-worm, 94, 105, 106, 186

Ant, ${ }_{5} 8$

Antiopa vanessa, 166

Aphids, II 5

A rabian days, $8 \mathrm{r}$

Arabian Nights, 61, 79, 88

Arethusa, 83

Azalia, 4, 6, 33

\section{B}

Bagdad, Caliph of, 76

Baptist, 53

Barberry, 32

Basilarchia astyanax, 71, 77, 79, 87

Basilarchia disippus, I6r

Bass, rock, 96

Bayberry, 8, 33, 45
Bee, 85,86, I $_{37}, I_{55}, I_{56}$, I 57 , 158 bumble, 137

Beetles, I6I

Berkshire hills, 135

Birch, 5, 8, 28, 29, 30, 93

Bittern, I42, I43

Blackberry, 56

high-bush, 33

Blackbird, I 43

Bladderwort, 64

Blueberry, high-bush, 50, 5I Bluebird, I75 I76, I77, I78, I79, I80, I8I, I82, I84, I92 Blue Hill, I35, I40, 202, 203

Blue Hill Reservation, 80, I 36

Bluejay, 226

Bobolink, 189

Brake, 43

Bream, 21 I

Bullhead, ror

Bulrush, $136,1_{3} 8$

Bunting, indigo, 189

Butterfly, angle-wing, 158

Anosia plexippus, I60, I65

Antiopa vanessa, I66

frittelaries, 159

meadow-brown, ${ }_{5} 8$ 


\section{INDEX}

Butterfly, monarch, r6o, r6r, I62, I7 I mourning cloak, 166 pearl crescent, ${ }_{5} 8$ white admiral, $7 x, 72$, $75,78,8 \mathrm{I}$

Button-bush, 4I, I4O

\section{C}

California, Gulf of, 213

Calvinists, 2 I 9

Camberwell beauty, 166

Carnations, 156

Cassandra, 52, 205

Cassius, 155

Catbird, 10, 14, 20, 21, 22, 23, 190, I91, 192

Caterpillar, 43

Cedar, 4, 5, 6, I5, 27, 29, I39, I $40, I_{4} I, 202,204,205,218$

Ceylon, 213

Chewink, I4

Clams, fresh-water, 95, I96

Clethra, 4, 35, I53, I55, I56

Compositæ, 4I

Coot, 183

Corydalis cornuta, 125

Cranberries, 139

Crow, 14, 18, I9, 20, 185, 187, I96, 197, 228

Cuckoo, 27, 225

\section{D}

Daisy, 4I

Delphos, 221
Demoiselles, I20, I 2 I, I22, I24, I26, 127

Dionaea, 206

Dorchester backwoods, 225

Dragon, I 28, I29

Dragon-flies, 56, 95, I20, I 2 I, I 22, 123

Drosera, 206

Duck, wood, I44, I45, I46, I49, I 5 a

E

Eel, I03, I04, 106, 107, I08, I 27

Eden, 127

Elm, 5I

\section{F}

Fern, 40, II2, II9

cinnamon, I I $2, \mathrm{II}_{3}$

ostrich-plume, 118

rock, II8, I I9

Fern seed, I I I, II3, II6, II9

Field mouse, 113

Finches, 10

Flag, sweet, I I 7

Flagroot, I I I

Flappers, I 44

Flea, 56

Floating-heart, I33, I35

Florida, rgr

Fly-catcher, great crested, 86 , 87,88

Flicker, 177

Fountain head, 8I 


\section{INDEX}

Fox, 6, 9, 13

Franklin Field, I42

Frog, 57, 59, 61, 66, I86

green, 42

Rana virescens, I86

G

Gall, I 5

Genie, 76, 88

Gentian, I34

Gerardia, 217

Goblin, water, I19, I20, I22, I25

Golchidium, 2II, 2 I2

Goldthread, I5

Grape, fox, $44,45,46$ wild, 5

Grass, fresh-water eel, I36 marsh, I38, I39, I4I tape, 136

Gratiola aurea, 224

Greenbrier, 15

\section{$\mathrm{H}$}

Habenaria, 86

Hardhack, 92, 205

Hasheesh, I30

Hawk, ro

Helgramite worm, I24, I25

Hepatica, 74

Heron, I97

$$
\text { night, } 140
$$

Hickory, 9, I 16

Holmes, Sherlock, I $_{5} \mathrm{O}$

Horn-pout, IOI, IO2, I03, IO4, I22, 127,2 II
Horse brier, I5 $_{5}$

Houghton's pond, 80

Huckleberry, 28, 29, 205

low-bush black, 34

$\mathrm{H} \mathrm{u} \mathrm{m} \mathrm{m} \mathrm{in} \mathrm{g-b} \mathrm{i} \mathrm{r} \mathrm{d,} \mathrm{r} \mathrm{u} \mathrm{b} \mathrm{y-}$ throated, 163

Hyla, 66

Hyssop, hedge, 223

\section{I}

Incas, 163

$\mathrm{J}$

Jasmine, Mexican, I63

Joe Pye weed, I4I

Jotham, 22I, 224

Judas, 167

June beetle, 59

K

"Kiver," 96, 97

L

Labrador, 80

Ladies' tresses, 2 I 7

Laurel, sheep, 205

Lepomis gibbosus, 96

Leprachaun, 78

Lilacs, 190

Lily, dog, 136 water, I34, I36, I37, I39, 2 I 2

Lily-of-the-valley, 74

Lucky bug, 53, 54, 63 


\section{INDEX}

M

Malachite, 207

Maple, 9, 51, 52, 62, 82, 92, 94, II6, I4I, 227,229

Meadow-sweet, 205

Memorial Day, 50

Merlin, 37, 39

Metropolitan Park Commission, 142

Milkweed, I 57, I 58, I59, I60

"Minister," Ior

Minnow, ro3

Mocking-bird, 2 I

Monarch butterfly, I60, I6r, I62, $17 \mathrm{I}$

Monitor, 54

Moss, sphagnum, $\mathbf{I}_{5}, 80,83$, 88, 142

Moth, I 55

luna, 65

Mourning-cloak butterfly, I66

Murray, "Adirondack," I48

Muskrat, 43, III, I42, I43, I99, 200

Myrica, 34

\section{$\mathrm{N}$}

Night heron, I40

Nymphæa, I39

Nymphs, I20, I22

\section{$\mathrm{O}$}

Oak, 5, 8, 9, 92 scrub, 15,190

Orchis, purple-fringed, 86
Oven bird, 16, 17, 23

Owl, Io

\section{$\mathbf{P}$}

Pan, 45

Panama, 163

Papilio asterias, I69

Partridge, 6, 37

Partridge berry, 74

Perch, yellow, 92, 99, I00, IO2, $\mathrm{IO}_{3}, \mathrm{I} 27$

Pickerel, 5I, 2 II

Pickerel weed, I36, I37, I38, I 39

Pine, 9, I5, I6, 28, 60, 73, 74, 77,88 , II2, I54, 2 I9, 228

Pipsissewa, 74

Plymouth Rock, 202

Polypody, 124

Ponkapoag pond, I33, I35

Poplars, 227, 229

Pumpkin seed, 96

Pyrola, 74

\section{Q}

Quail, 220, 222

\section{$\mathrm{R}$}

Rana virescens, I86

Raspberry, 5

Robin, 10, 13, I89

Rocket, sweet, $\mathrm{I}_{62}, \mathrm{I}_{3}$

Rose, wild, 4, 8, 52, 205 


\section{INDEX}

\section{S}

Santo Doningo, I9I

Sassafras, 5, 232

Sedges, 56, 60

Skipper, 63

Skunk, 198

Skunk cabbage, 40

Snake, water, I26, I27

Sparrow, chipping, I2, 178

English, 176, 178, 179, I80, $18 \mathrm{I}, 183$

song, I 3

Sphagnum moss, I $_{5}, 80,83$, 88, I 42

Spiræa, 52

Spiranthes gracilis, 217

Squirrel, 197, 198

gray, 62,63

red, 6

Standish, Myles, I35, 202

Stephanotis, I63

St. John's-wort, marsh, 206

Strawberries, wild, 33

Stumpy Cove, 201, 202

Submarine, 54

Sulu, 2 I3

Sunda, straits of, $2 \mathrm{I}_{3}$

Sunfish, 92, 95, 96, 98, 99, 100, 103, 126, 127

Sweet-fern, 8, 33, 35, 45, I54, 205

Sweet-gale, 34, 45, 52

$\mathrm{T}$

Tanager, scarlet, $\mathrm{r} 88$

Terrapin, $84,85,88$

I6
Texas, 158

Thoroughwort, I4I

Thrasher, I4

Thrush, Io, 20, 30, 3I, 35

brown, $2 \mathrm{I}, 28$

wood, II, I2, I7

Toad, 66, 129

Torpedo boat, 54, 99

Trout, 82, 84, 96, 122

Turtle, spotted, $83,84,85,88$

U

Ulysses, 64

Unio, 196, 199, 209, 210

Unio margaritifera, 195, 209,

2 I 4

Unionidæ, 207

Utricularia, 64

V

Venus' fly-trap, 206

Viceroy butterfly, I6I

Vireo, II9

\section{W}

Walden pond, 80

Warblers, I0, 14

Wasps, r6r

Watercress, $82,83,86$

Water shield, 136

Water-strider, 55

Watson, Doctor, 150 


\section{INDEX}

Whip-poor-will, 30, 31, 35

Wild rose, 4, 8, 52, 205

Willows, 92, 94, 98, 227, 229

Witch, II4, I25
Witch caps, II5

Witch-hazel, II2, II3, II4, II 5, II6, II7, I24, I25, I29 Woodbine, 4

Woodchuck, 9 



